\title{
Synthesis of a Suite of Click-Compatible Sugar Analogs for Probing Carbohydrate Metabolism
}

\author{
Bo Wang ${ }^{1,3}$, Daniel D. McClosky ${ }^{2,3}$, Charles T. Anderson ${ }^{2,3 *}$ and Gong Chen ${ }^{1,3,4 *}$
}

${ }^{1}$ Department of Chemistry, The Pennsylvania State University, University Park, Pennsylvania 16802, United States of America

${ }^{2}$ Department of Biology, The Pennsylvania State University, University Park, Pennsylvania 16802, United States of America

${ }^{3}$ Center for Lignocellulose Structure and Formation, The Pennsylvania State University, University Park, Pennsylvania, 16802, United States of America

${ }^{4}$ State Key Laboratory and Institute of Elemento-Organic Chemistry, Collaborative Innovation Center of Chemical Science and Engineering (Tianjin), Nankai University, Tianjin 300071, China

* Corresponding authors:

Email: Charles T. Anderson: cta3@psu.edu

Gong Chen: guc11@psu.edu, gongchen@nankai.edu.cn

\begin{abstract}
Metabolic labeling based on the click chemistry between alkynyl and azido groups offers a powerful tool to study the function of carbohydrates in living systems, including plants. Herein, we describe the chemical synthesis of six alkynyl-modified sugars designed as analogs to D-glucose, D-mannose, L-rhamnose and sucrose present in plant cell walls. Among these new alkynyl probes, four of them are the 6-deoxy-alkynyl analogs of the corresponding sugars and do
\end{abstract}


not possess any 6-OH groups. The other two are based on a new structural design, in which an ethynyl group is incorporated at the $\mathrm{C}-6$ position of the sugar and the 6-OH group remains. The synthetic routes for both types of probes share common aldehyde intermediates, which are derived from the corresponding 6-OH precursor with other hydroxy groups protected. The overall synthesis sequence of these probes is efficient, concise, and scalable.

Keywords: click chemistry, labeling probe, carbohydrate metabolism

\section{Introduction}

Organisms throughout the tree of life coat their cell exteriors with carbohydrates. These coatings are heterogeneous, complex, and dynamic. Carbohydrates can have multiple levels of structural complexity: unlike linear peptides and nucleic acids, polysaccharides are often branched and can be constructed from many building-block monosaccharide monomers ${ }^{1-4}$. Despite the structural complexity of carbohydrate polymers, monosaccharides are quite uniform from a functional-group perspective. This presents a dilemma to researchers interested in detecting and distinguishing individual types of polysaccharides in cells, often forcing them to rely on higher-order carbohydrate organizations that can form epitopes for immunodetection. A new and powerful method to detect specific carbohydrates is through orthogonal metabolic labeling $^{5-7}$. In this approach, synthetic sugar analogs serve as chemical reporters. They are introduced to cells, which then incorporate them into native polysaccharides, installing a functional group that is not otherwise present in the organism. This functional group can then be detected by taking advantage of a bioorthogonal 'click' reaction to couple it to a small-molecule detection probe. This strategy, termed 'click-labeling', has enabled carbohydrate imaging in diverse taxa, including vertebrates, bacteria, and plants ${ }^{8-10}$. 
A) 6-Alkynyl fucose probe

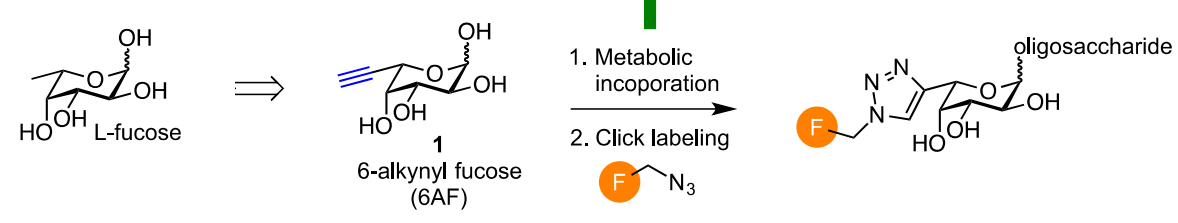

B) Expanding the toolbox of alkynyl sugars
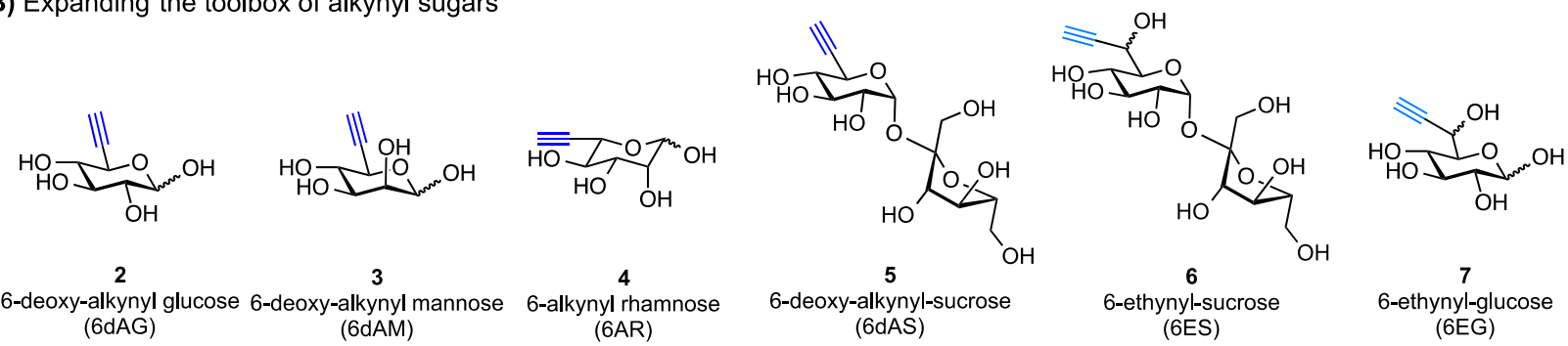

Scheme 1. Expanding the toolbox of 6-deoxy-alkynyl sugar probes for metabolic click labeling of oligosaccharides.

The plant cell wall is a particularly enigmatic and interesting structure, which must be strong to ensure the mechanical integrity of plant tissues, but must also permit tightly-controlled nanoscale loosening that results in cell expansion and determines cell shape ${ }^{11-13}$. The walls of growing plant cells contain four major components: rigid, load-bearing cellulose ${ }^{14}$; other glycans grouped as hemicelluloses ${ }^{15}$; acidic gel-forming pectins ${ }^{16}$; and a variety of proteins ${ }^{17}$. Despite intense current interest in understanding plant cell wall structure and how it changes in vivo, only three examples of click-labeling plant cell wall components have been reported ${ }^{8,18}$. In the first study, researchers used a fucose analog 1, 6-deoxy-alkynyl fucose (6AF), as a chemical reporter for pectin (Scheme 1A) ${ }^{8}$. Alkyne groups in the apoplast were then detected with azide-modified probes, taking advantage of the rapid, selective copper-catalyzed alkyne-azide cyclization (CuAAC) reaction. With this method, pectin delivery and distribution can be monitored in diffusely-expanding cells. In the second study, the authors used azido 3-deoxy-D-manno-oct-2-ulosonic acid (Kdo) to label another form of pectin ${ }^{18}$, and in the third study, we reported the use of 6-deoxy-6-alkynyl glucose to label an unknown wall component in the tips of root hairs ${ }^{19}$. In the present study, we describe the chemical synthesis of six additional 
alkyne-carried sugars designed as analogs to three other sugars that present in plant cell walls (Scheme 1B): glucose, which forms the backbone of cellulose and xyloglucan; rhamnose, which is a 6-deoxy-sugar component of two pectin polysaccharides, rhamnogalacturonan-I and

rhamnogalacturonan- $\mathrm{II}^{20-22}$; and mannose, which is present in glycosylated proteins and also in mannans, a hemicellulose class that is enriched in walls that are deposited after the cessation of cell growth ${ }^{4}$. Among these new alkynyl probes, four are the 6-deoxy-alkynyl analogs of the corresponding sugars and therefore do not possess 6-OH groups. The other two are based on a new structural design, in which an ethynyl group is incorporated at the C6 position of sugar, and the 6-OH group remains. The synthetic routes we developed featuring the use of methoxymethyl (MOM) and triethylsilyl (TES) protecting groups are efficient and concise. Although they were originally designed to report on plant cell wall polysaccharides, these sugar analogs could prove to be useful reporters for polysaccharides in diverse living systems.

\section{Results and discussion}

\subsection{Synthesis of 6-alkynyl aldohexoses 2,3 and 4}

Although a number of azido-substituted analogs for common monosaccharides have been synthesized and even commercially available, we previously found that 6-deoxy-azidofucose is not efficiently incorporated into plant cell walls as compared to 6-alkynyl fucose $\mathbf{1}(6 \mathrm{AF}) .^{8}$ Thus, we have sought to expand the toolbox of 6-alkynyl monosaccharides to allow for the study of wall polysaccharides that contain other aldohexoses and deoxyaldohexoses, such as glucose, galactose, xylose, rhamnose, and arabinose. An initial strategy to prepare the 6-alkynyl aldohexoses is to first selectively oxidize the 6-OH group to an aldehyde and then use the Seyferth-Gilbert reaction to install the terminal alkynyl group (Scheme 2A). The key to achieve an efficient and practical synthesis of these compounds is to use proper $\mathrm{OH}$ protecting groups, which are compatible with the homologation reaction and also allow facile protection and deprotection. Acetate and benzyl, two of the mostly commonly used protecting groups for sugar 
synthesis, cannot be used due to the basic conditions required for the Seyferth-Gilbert reaction and the sensitivity of alkynyl group under hydrogenation conditions. Use of two acetonide protecting groups has been successfully applied for the synthesis of 6-akynyl fucose 1 (Scheme $2 \mathrm{~B})^{5}$. However, most of the other hexoses cannot be properly protected by acetonides, so new protecting strategies are necessary.

A) General synthesis strategy

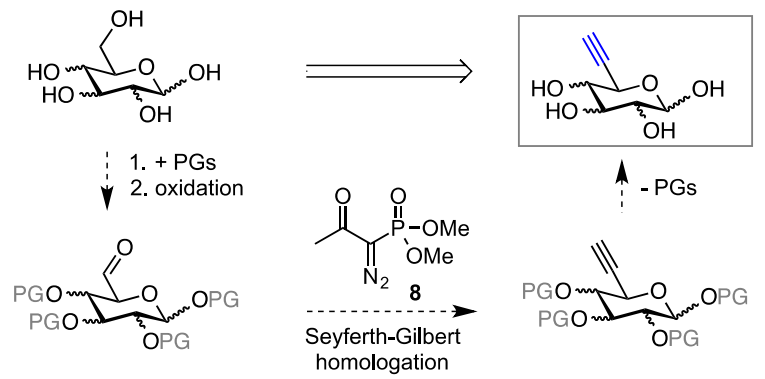

B) Reported synthesis of fucose 1
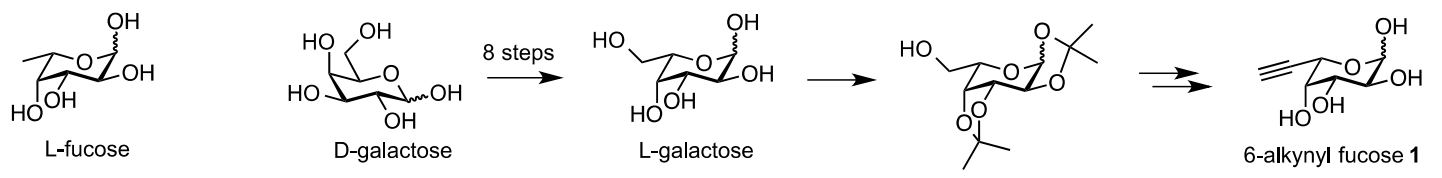

C) 1st generation synthesis of 6-deoxy-alkynyl mannose 3
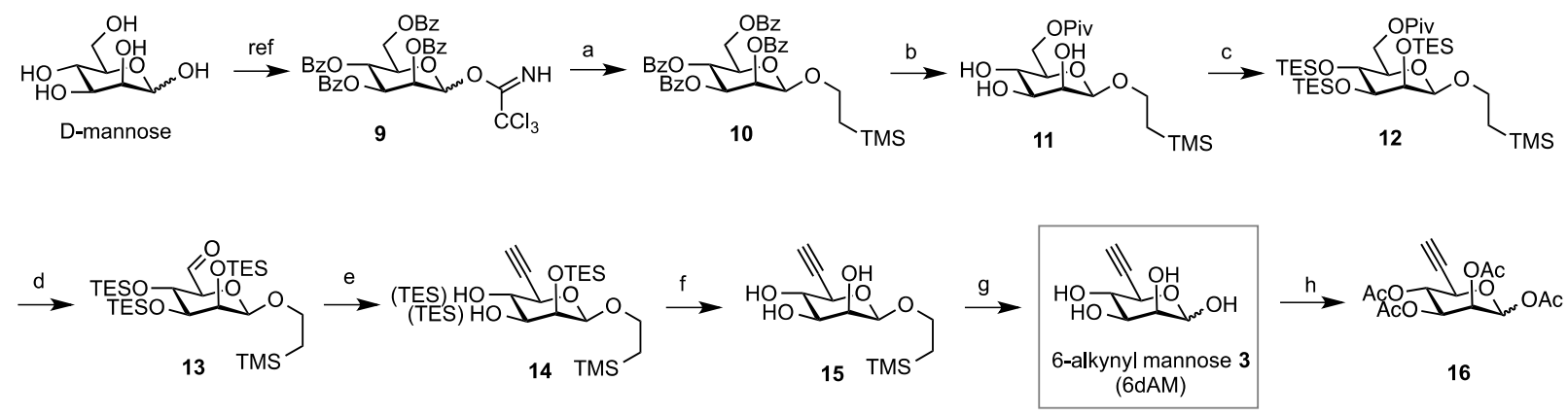

D) 2nd generation synthesis of 3

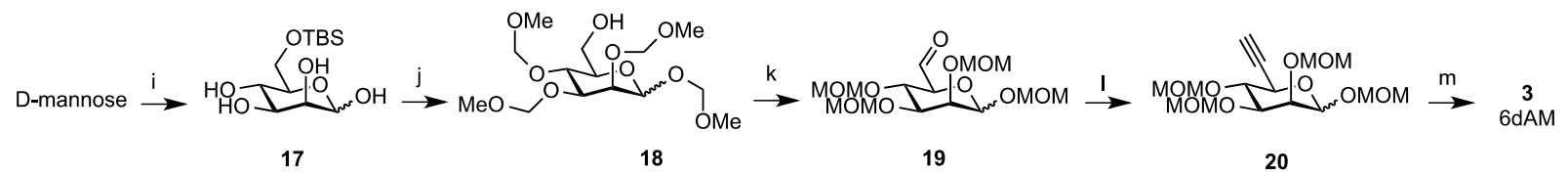

Scheme 2. Synthesis of 6-deoxy-alkynyl mannose 3. Reagents and conditions: a) 
2-(Trimethylsilyl)ethanol, TMSOTf, dichloromethane (DCM), rt, 0.5 h, 92\%; b) $\mathrm{K}_{2} \mathrm{CO}_{3}, \mathrm{MeOH}$, $\mathrm{rt}, 1 \mathrm{~h}$, then PivCl, pyridine (Py), $0{ }^{\circ} \mathrm{C}, 12 \mathrm{~h}, 52 \%$ over two steps; c) TESOTf, triethylamine (TEA), DCM, rt, $3 \mathrm{~h}, 86 \%$; d) DIBAL-H, DCM, $-78{ }^{\circ} \mathrm{C}$, $1 \mathrm{~h}$ then DMP, DCM, 5h, 91\%; e) 8, $\mathrm{K}_{2} \mathrm{CO}_{3}$, $\mathrm{MeOH}, \mathrm{rt}, 12 \mathrm{~h}$; f) TBAF, THF, rt, $1 \mathrm{~h}, 72 \%$ over two steps; g) $0.1 \%$ aq. $\mathrm{H}_{2} \mathrm{SO}_{4}, 80{ }^{\circ} \mathrm{C}, 12 \mathrm{~h}, 79 \%$; h) $\mathrm{Ac}_{2} \mathrm{O}, \mathrm{Py}, 12 \mathrm{~h}, 88 \%$; i) TBSCl, Py, 12h, 50\%; j) MOMCl, TBAI, THF, reflux, 12h, then TBAF, THF, rt, $1 \mathrm{~h}, 83 \%$ over two steps; k) DMP, DCM, 5h; 1) 8, $\mathrm{K}_{2} \mathrm{CO}_{3}$, MeOH, rt, $60 \%$ over two steps; m) $0.1 \%$ aq. $\mathrm{H}_{2} \mathrm{SO}_{4}, 80{ }^{\circ} \mathrm{C}, 12 \mathrm{~h}, 68 \%$.

To synthesize 6-deoxy-alkynyl-D-mannose (6dAM) 3, we firstly tested a silyl-based protecting group strategy (Scheme 2C). Benzoyl (Bz) protected D-mannosyl tricholoacetimidatedonor 9 prepared following the reported procedure ${ }^{23}$ reacted with trimethylsilylethanol to give compound $\mathbf{1 0}$. The $\mathrm{OBz}$ groups of $\mathbf{1 0}$ were then removed by the treatment of $\mathrm{K}_{2} \mathrm{CO}_{3}$ in $\mathrm{MeOH}$ and the 6-OH group was selectively protected by pivaloyl chloride $(\mathrm{PivCl})$. The remaining $\mathrm{OH}$ groups were then protected with triethylsilyltrifluoromethanesulfonate (TESOTf) to give compound 12. Treatment of 12 with diisobutylaluminium hydride (DIBAL-H) selectively removed OPiv, and the 6-OH intermediate was oxidized by Dess-Martin periodinane (DMP) to give compound 13. Reaction of 13 with Bestmann's reagent 8 under the typical Seyferth-Gilbert conditions gave compound $\mathbf{1 4}$ along with a mixture of partially TES-removed products. Treatment of the mixed products with tetra- $n$-butylammonium fluoride (TBAF) at room temperature (rt) gave compound $\mathbf{1 5}$ in good yield. Treatment of 15 with $0.1 \%$ aq. $\mathrm{H}_{2} \mathrm{SO}_{4}$ cleanly gave the desired product $6 \mathrm{dAM} 3$ as an anomeric mixture. Treatment of $\mathbf{3}$ with $\mathrm{Ac}_{2} \mathrm{O}$ gave the corresponding peracetylated product $\mathbf{1 6}$.

Although this route provided the desired products, it required lengthy protecting group manipulations. A 2nd generation synthesis of compound $\mathbf{3}$ featuring the use of methoxymethyl (MOM) group was then developed. The 6-OH group of D-mannose was first selectively protected by tert-butyldimethylsilyl (TBDMS) group to give compound 17. The remaining $\mathrm{OH}$ groups of $\mathbf{1 7}$ were then protected by MOM, followed by the removal of the TBDMS group by 
TBAF to liberate the 6-OH group to give 18. The 6-OH group of $\mathbf{1 8}$ was oxidized by DMP to form the corresponding aldehyde 19. The aldehyde was then converted to alkyne 20 under the standard Seyferth-Gilbert conditions with Bestmann's reagent 8. Global deprotection of MOM groups by the treatment of $0.1 \%$ aq. $\mathrm{H}_{2} \mathrm{SO}_{4}$ gave the desired product 3 in excellent yield and purity. Compared to the $1^{\text {st }}$ generation synthesis of $\mathbf{3}$, the new route only involves six total steps, uses two common protecting groups TBDMS and MOM, requires three silica gel chromatograph separations, and is suitable for gram scale synthesis.

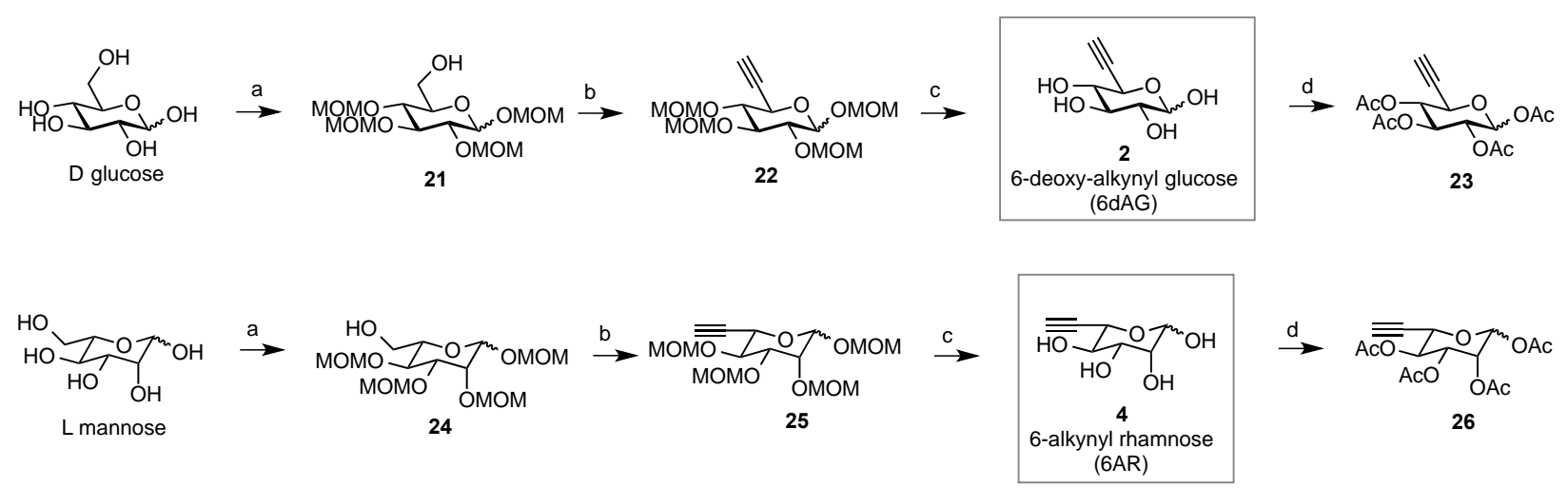

Scheme 3.Synthesis of 6-deoxy-alkynyl glucose 2 and 6-alkynyl rhamnose 4. Reagents and conditions: a) TBSCl, Py, 12h, 46\% for D-glucose, 54\% for L-mannose; b) MOMCl, TBAI, THF, reflux, $12 \mathrm{~h}$, then TBAF, THF, rt, $1 \mathrm{~h}, 88 \%$ for $\mathbf{2 1}, 76 \%$ for $\mathbf{2 4}$; c) DMP, DCM, 5h; d) $\mathbf{8}, \mathrm{K}_{2} \mathrm{CO}_{3}$, $\mathrm{MeOH}, \mathrm{rt}, 12 \mathrm{~h}, 67 \%$ for $22,55 \%$ for $\mathbf{2 5}$; e) $0.1 \% \mathrm{H}_{2} \mathrm{SO}_{4}, 80{ }^{\circ} \mathrm{C}, 12 \mathrm{~h}, 80 \%$ for $\mathbf{2}, 70 \%$ for 4 .

As shown in Scheme 3, the new synthesis strategy for 6-deoxy-alkynyl sugar can be readily applied to the synthesis of 6-deoxy-alkynyl-glucose (6dAG) 2 and 6-alkynyl-rhamnose (6AR) 4. It should be noted that 6AR 4 was prepared from a L-mannose precursor.

\subsection{Synthesis of 6-deoxy-alkynyl sucrose 5}



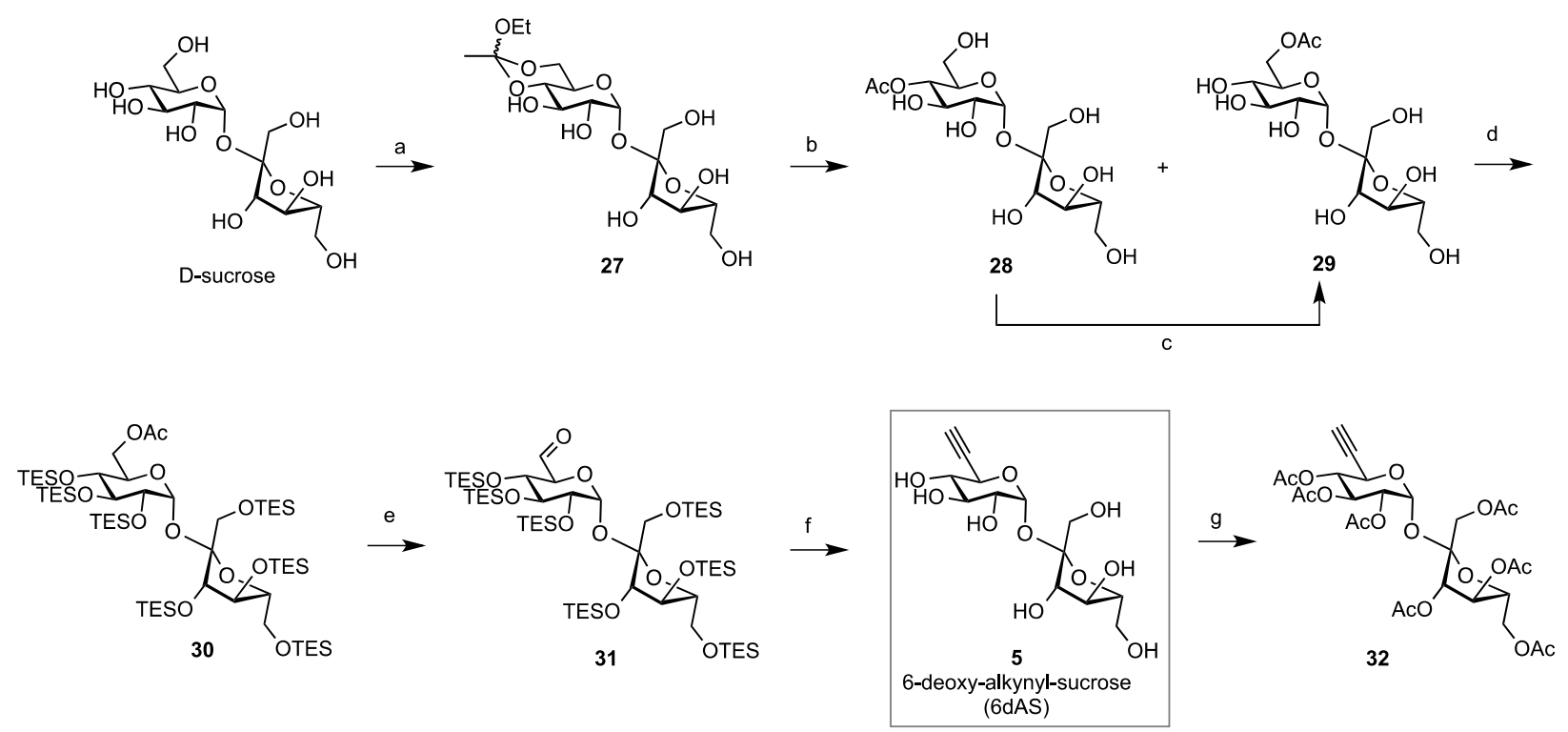

Scheme 4. Synthesis of 6-deoxy-alkynyl sucrose 5. Reagents and conditions: a) triethylorthoacetate, $p$-TsOH, DMF, rt, 3h; b) $\mathrm{H}_{2} \mathrm{O}$, rt, $1 \mathrm{~h}$ (one pot operation for steps a and b); c) $t$-BuNH 2, rt, 1.5h, 44\% over three steps; d) TESOTf, TEA, DCM, rt, 12h, then DIBAL-H, DCM, $-78{ }^{\circ} \mathrm{C}, 1 \mathrm{~h}, 88 \%$; e) DMP, DCM, 5h, rt; f) $8, \mathrm{~K}_{2} \mathrm{CO}_{3}, \mathrm{MeOH}, \mathrm{rt}, 12 \mathrm{~h}$, then TBAF, THF, rt, $1 \mathrm{~h}$; g) $\mathrm{Ac}_{2} \mathrm{O}, \mathrm{Py}, 12 \mathrm{~h}, 40 \%$ over four steps.

In addition to the monosaccharides mentioned above, the disaccharide sucrose is the major transport form for photo-assimilated carbon and is also a source of carbon skeletons for plant organs unable to perform photosynthesis ${ }^{24}$. We hypothesized that sucrose carrying a click-compatible groups could also be potentially used by the plant cell. The synthesis of the corresponding 6-deoxy alkynyl analog 5 was developed accordingly as shown in Scheme 4. The 4,6-diol moiety of glucose unit in sucrose was selectively protected by orthoester to give compound 27, which can be then hydrolyzed under acidic conditions to give a mixture of 4-OAc compound 28 and 6-OAc compound 29. Treatment of the mixture of 28 and 29 with $t$ - $\mathrm{BuNH}_{2}$ affected the acyl migration from O-4 to O-6 in 28, giving 6-OAc compound 29 as the major product. The remaining $\mathrm{OH}$ groups of $\mathbf{2 9}$ were then protected with TES groups to give $\mathbf{3 0}$. The OAc group of $\mathbf{3 0}$ was then selectively removed and the liberated 6-OH group was oxidized to give the corresponding aldehyde. Reaction of $\mathbf{3 1}$ with Bestmann's reagent $\mathbf{8}$ under the standard 
Seyferth-Gilbert conditions gave the desired 6-deoxy-alkynyl sucrose (6dAS) 5. Treatment of 5 with acetic anhydride gave the per-acetylated product $\mathbf{3 2}$.

\subsection{Synthesis of 6-ethynyl sucrose 6 and 6-ethynyl-sucrose 7}

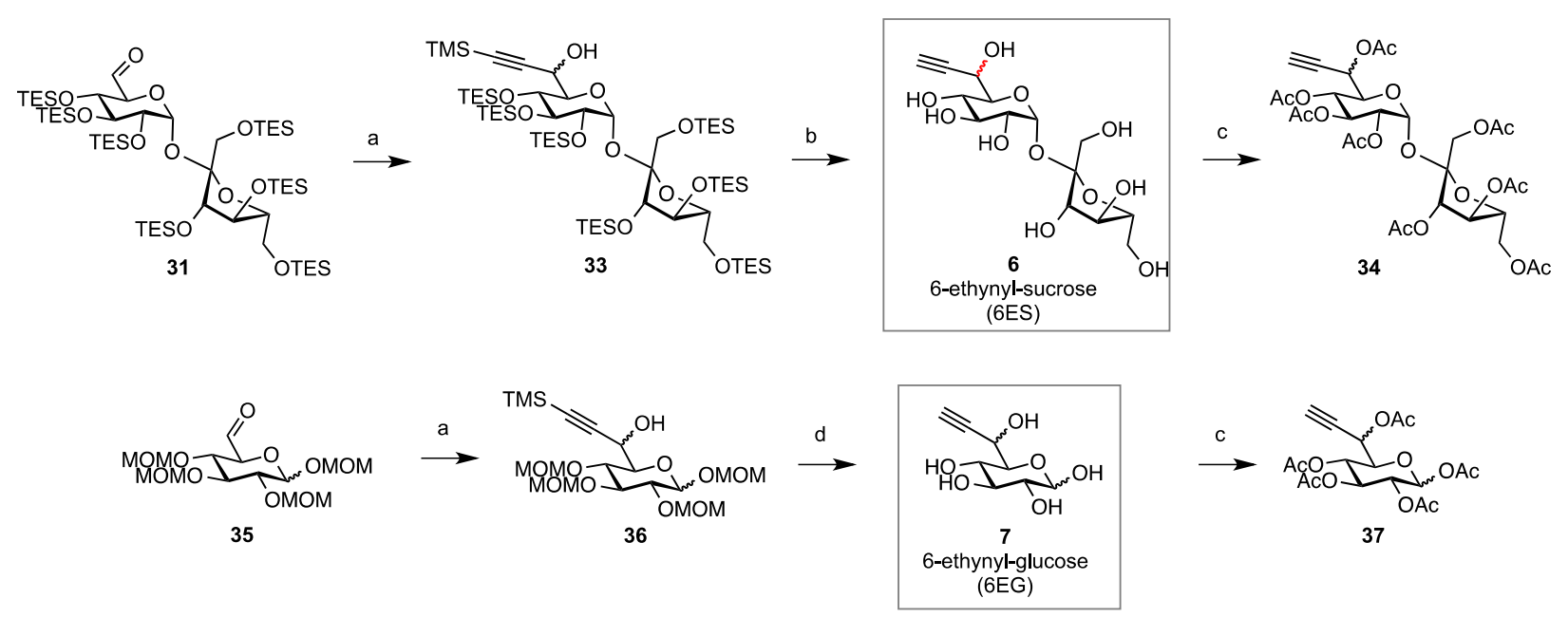

Scheme 5. Synthesis of 6-ethynyl sucrose 6 and 6-ethynyl-sucrose 7. Reagents and conditions: a) trimethylsilylacetylene, $n$-BuLi, THF, $-78{ }^{\circ} \mathrm{C}, 85 \%$ for $\mathbf{3 3}, 82 \%$ for $\mathbf{3 6}$; b) TBAF, THF, rt, $12 \mathrm{~h}$, $68 \%$; c) $\mathrm{Ac}_{2} \mathrm{O}, \mathrm{Py}, 12 \mathrm{~h}, 88 \%$ for $\mathbf{3 4}, 53 \%$ for 37 from 35; d) TBAF, THF, rt, $1 \mathrm{~h}$, then $0.1 \%$ aq. $\mathrm{H}_{2} \mathrm{SO}_{4}, 80{ }^{\circ} \mathrm{C}, 12 \mathrm{~h}, 73 \%$.

Complementary to the above-mentioned 6-deoxy-alkynyl analogs of sugars, we also investigated a new way to incorporate an alkynyl tag to the sugar substrates by installing an ethynyl group at the $\mathrm{C}-6$ position and keeping the 6-OH group. As shown in Scheme 5, nucleophilic addition of TMS-protected ethynylene lithium salt to sucrose aldehyde $\mathbf{3 1}$ formed the alcohol compound $\mathbf{3 3}$ as a diastereomeric mixture in good yield. Global deprotection of the TES group by TBAF gave the desired 6-ethynyl sucrose $\mathbf{6}$ in good yield. Treatment of $\mathbf{6}$ with $\mathrm{Ac}_{2} \mathrm{O}$ gave peracetylated 34. Similarly, reaction of TMS ethynylene with MOM-protected glucose aldehyde $\mathbf{3 5}$ gave compound $\mathbf{3 6}$ in good yield. Deprotection of TMS and MOM of $\mathbf{3 6}$ 
followed by per-acetylation gave the corresponding compound $\mathbf{3 5}$ in good yield over four steps.

\section{Conclusion}

We reported the synthesis of six alkynyl-modified sugar probes designed as analogs to sugars present in plant cell walls. Among these new alkynyl probes, four are the 6-deoxy-alkynyl analogs of the corresponding sugars and do not possess any 6-OH groups. The other two are based on a new structural design, in which an ethynyl group is incorporated at the C-6 position of sugar and the 6-OH group remains. The synthetic routes for both types of probes share common aldehyde intermediates. The aldehydes can either undergo a one-carbon homologation to give the deoxy-alkynyl products or undergo a 1,2-addition with an ethylene reagent to introduce a two-carbon unit at the C-6 position. The overall synthesis sequence of these probes is efficient, concise and scalable. We expect that these probes will find broad application in the metabolic labeling studies of carbohydrates in diverse living systems.

\section{Experimental sections:}

\subsection{General methods}

All commercial materials were used as received unless otherwise noted. The tetrahydrofuran and dichloromethane for reaction were obtained from a JC Meyer solvent dispensing system and used without further purification. Flash chromatography was performed using 230-400 mesh SiliaFlash 60® silica gel (Silicycle Inc.). Other commonly used reagents were all purchased from Sigma-Aldrich, and used as received without further treatment. NMR spectra were recorded on BrukerAV-3-HD-500 or Bruker CDPX-300 instrument and calibrated using residual solvent peaks as internal reference. Multiplicities are recorded as: $\mathrm{s}=$ singlet, $\mathrm{d}=$ doublet, $\mathrm{t}=$ triplet, $\mathrm{dd}$ 
$=$ doublet of doublets, $\mathrm{m}=$ multiplet, $\mathrm{q}=$ quartet. High resolution ESI mass experiments were operated on a Waters LCT Premier instrument.

\subsection{Synthesis of compound $3(6 d A M)$ in Scheme $2 C$}

\subsubsection{2-(Trimethylsilyl)ethyl 2,3,4,6-tetra-O-benzoyl- $\alpha$-D-mannopyranoside (10)}

Compound 9 was prepared according to the reported procedure ${ }^{23}$. To a solution of compound 9 (1.48 g, $2.0 \mathrm{mmol}, 1$ equiv) and 2-(trimethylsilyl)ethanol (354 mg, $3.0 \mathrm{mmol}, 1.5$ equiv) in DCM $(50 \mathrm{~mL})$ was added TMSOTf $(16.3 \mu \mathrm{L}, 0.1 \mathrm{mmol}, 0.05$ equiv) at rt. The reaction mixture was stirred at $\mathrm{rt}$ for $0.5 \mathrm{~h}$, then quenched by the addition of TEA $(100 \mu \mathrm{L})$. The reaction mixture was diluted with DCM $(50 \mathrm{~mL})$, and washed thoroughly with water and brine. The organic layer was dried over anhydrous $\mathrm{Na}_{2} \mathrm{SO}_{4}$ and concentrated in vacuo. The resulting residue was purified by silica gel flash chromatography (hexanes : ethyl acetate $=2: 1$ ) to give $1.28 \mathrm{~g}$ of compound $\mathbf{1 0}$ as a white foam in $92 \%$ yield. ${ }^{1} \mathrm{H}$ NMR $\left(500 \mathrm{MHz}, \mathrm{CDCl}_{3}\right) \delta 8.16-8.06(\mathrm{~m}, 4 \mathrm{H}), 8.02-7.95(\mathrm{~m}$, 2H), $7.90-7.83(\mathrm{~m}, 2 \mathrm{H}), 7.65-7.57(\mathrm{~m}, 2 \mathrm{H}), 7.53(\mathrm{t}, J=7.4 \mathrm{~Hz}, 1 \mathrm{H}), 7.49-7.36(\mathrm{~m}, 7 \mathrm{H}), 7.31$ $-7.27(\mathrm{~m}, 2 \mathrm{H}), 6.11(\mathrm{t}, J=9.9 \mathrm{~Hz}, 1 \mathrm{H}), 5.96(\mathrm{dd}, J=10.1,3.3 \mathrm{~Hz}, 1 \mathrm{H}), 5.70(\mathrm{dd}, J=3.1,1.8 \mathrm{~Hz}$, $1 \mathrm{H}), 5.15(\mathrm{~d}, J=1.4 \mathrm{~Hz}, 1 \mathrm{H}), 4.72(\mathrm{dd}, J=11.6,1.8 \mathrm{~Hz}, 1 \mathrm{H}), 4.59-4.45(\mathrm{~m}, 2 \mathrm{H}), 4.01-3.89$ (m, 1H), $3.76-3.66(\mathrm{~m}, 1 \mathrm{H}), 1.20-1.01(\mathrm{~m}, 2 \mathrm{H}), 0.09(\mathrm{~s}, 9 \mathrm{H}) ;{ }^{13} \mathrm{C} \mathrm{NMR}\left(126 \mathrm{MHz}, \mathrm{CDCl}_{3}\right) \delta$ $=166.22,165.54,165.52,165.49,133.45,133.15,133.08,129.87,129.84,129.75,129.42$, $129.16,129.03,128.60,128.46,128.30,70.80,70.14,68.85,67.11,66.20,63.12,18.02,-1.36$; HRMS: calculated for $\mathrm{C}_{39} \mathrm{H}_{41} \mathrm{O}_{10} \mathrm{Si}^{+}\left[\mathrm{M}+\mathrm{H}^{+}\right]$: 697.2464; found: 697.2450.

\subsubsection{2-(Trimethylsilyl)ethyl 6-O-pivaloyl- $\alpha$-D-mannopyranoside (11)}

To a solution of compound 10 (1.20 g, $1.7 \mathrm{mmol}, 1$ equiv) in $\mathrm{MeOH}(100 \mathrm{~mL})$ was added $\mathrm{K}_{2} \mathrm{CO}_{3}(100 \mathrm{mg})$, and the resulting solution was stirred at $\mathrm{rt}$ for 1 . After concentration in vacuo to remove the methanol, the residue was re-dissolved in pyridine $(50 \mathrm{~mL})$ and cooled in ice-water bath. To the reaction mixture was added pivaloyl chloride ( $290 \mu \mathrm{L}, 3.4 \mathrm{mmol}, 2$ equiv) dropwise. 
The resulting mixture was stirred at $0{ }^{\circ} \mathrm{C}$ overnight, the reaction was then quenched by the addition of $\mathrm{MeOH}(1 \mathrm{~mL})$. The reaction mixture was concentrated in vacuo, and the resulting residue was purified by silica gel flash chromatography (hexanes : ethyl acetate $=1: 1$ ) to give $320 \mathrm{mg}$ of compound $\mathbf{1 1}$ as a white foam in 52\% yield over two steps. ${ }^{1} \mathrm{H}$ NMR (300 MHz, $\left.\mathrm{CDCl}_{3}\right) \delta 4.78(\mathrm{~s}, 1 \mathrm{H}), 4.60(\mathrm{~s}, 1 \mathrm{H}), 4.48(\mathrm{~s}, 1 \mathrm{H}), 4.40-4.20(\mathrm{~m}, 2 \mathrm{H}), 4.09(\mathrm{~s}, 1 \mathrm{H}), 3.88(\mathrm{~s}, 1 \mathrm{H})$, $3.84-3.67(\mathrm{~m}, 3 \mathrm{H}), 3.61(\mathrm{t}, J=9.2 \mathrm{~Hz}, 1 \mathrm{H}), 3.53-3.39(\mathrm{~m}, 1 \mathrm{H}), 1.18(\mathrm{~s}, 9 \mathrm{H}), 0.97-0.84(\mathrm{~m}$, 2H), -0.01 (s, 9H); ${ }^{13} \mathrm{C}$ NMR (75 MHz, $\left.\mathrm{CDCl}_{3}\right) \delta=179.56,99.63,72.07,71.26,70.96,68.42$, 65.45, 64.78, 39.26, 27.64, 18.31, -0.92; HRMS: calculated forC ${ }_{16} \mathrm{H}_{33} \mathrm{O}_{7} \mathrm{Si}^{+}\left[\mathrm{M}+\mathrm{H}^{+}\right]$: 365.1990; found: 365.1993 .

\subsubsection{2-(Trimethylsilyl)ethyl 2,3,4-tri-O-triethylsilyl 6-O-pivaloyl- $\alpha$-D-mannopyranoside (12)}

To an ice-water cooled solution of compound 11 (300 mg, $0.82 \mathrm{mmol}, 1$ equiv) and triethylamine $(1.1 \mathrm{~mL}, 8.2 \mathrm{mmol}, 10$ equiv) in DCM $(30 \mathrm{~mL})$ was added TESOTf $(1.1 \mathrm{~mL}, 4.9$ mmol, 6 equiv) dropwise. The reaction mixture was stirred at $\mathrm{rt}$ for $3 \mathrm{~h}$, and then quenched by the addition of $\mathrm{MeOH}(5 \mathrm{~mL})$. The reaction mixture was concentrated in vacuo, and the resulting residue was purified by silica gel flash chromatography (hexanes : ethyl acetate $=30: 1$ ) to give $500 \mathrm{mg}$ of compound 12 as a colorless oil in $86 \%$ yield. ${ }^{1} \mathrm{H} \mathrm{NMR}\left(300 \mathrm{MHz}, \mathrm{CDCl}_{3}\right) \delta 4.98(\mathrm{dd}$, $J=7.3,2.8 \mathrm{~Hz}, 1 \mathrm{H}), 4.60(\mathrm{~d}, J=3.0 \mathrm{~Hz}, 1 \mathrm{H}), 4.08-3.91(\mathrm{~m}, 2 \mathrm{H}), 3.85-3.68(\mathrm{~m}, 3 \mathrm{H}), 3.61-$ $3.50(\mathrm{~m}, 1 \mathrm{H}), 3.50-3.36(\mathrm{~m}, 1 \mathrm{H}), 1.23(\mathrm{~s}, 10 \mathrm{H}), 0.99-0.89(\mathrm{~m}, 29 \mathrm{H}), 0.67-0.53(\mathrm{~m}, 18 \mathrm{H})$,

$0.01(\mathrm{~s}, 9 \mathrm{H}) ;{ }^{13} \mathrm{C}$ NMR $\left(75 \mathrm{MHz}, \mathrm{CDCl}_{3}\right) \delta=178.43,100.30,76.07,75.01,70.79,67.52,65.22$, 62.99, 39.37, 27.85, 18.35, 7.33, 7.21, 5.46, 4.95, -0.96; HRMS: calculated forC ${ }_{34} \mathrm{H}_{75} \mathrm{O}_{7} \mathrm{Si}_{4}{ }^{+}\left[\mathrm{M}+\mathrm{H}^{+}\right]:$707.4584; found: 707.4575.

\subsubsection{2-(Trimethylsilyl)ethyl 2,3,4-tri-O-triethylsilyl $\alpha$-D-manno-hexodialdo-1,5-pyranoside (13)}

To a solution of compound 12 (400 mg, $565.5 \mu \mathrm{mol}, 1$ equiv) in DCM (30 mL) at $-78{ }^{\circ} \mathrm{C}$ was added DIBAL-H (0.69 mL, $1.1 \mathrm{mmol}, 2$ equiv, $1.6 \mathrm{M}$ solution in hexanes) dropwise. The reaction was stirred at $-78{ }^{\circ} \mathrm{C}$ for $1 \mathrm{~h}$, and then quenched by the addition of saturated aq. $\mathrm{NH}_{4} \mathrm{Cl}$ 
solution $(10 \mathrm{~mL})$. The reaction was diluted with DCM $(50 \mathrm{~mL})$, and washed thoroughly with water and brine. The organic layer was dried over anhydrous $\mathrm{Na}_{2} \mathrm{SO}_{4}$ and concentrated in vacuo. The resulting residue was used for next step without further purification. To a solution of the residue in DCM (20 mL) at rt was added Dess-Martin periodinane (480 mg, $1.1 \mathrm{mmol}, 2$ equiv), and the resulting reaction mixture was stirred at $\mathrm{rt}$ for $5 \mathrm{~h}$. The reaction mixture was diluted with DCM (50 mL), and washed thoroughly with saturated aq. sodium thiosulfate solution, water and brine. The organic layer was dried over anhydrous $\mathrm{Na}_{2} \mathrm{SO}_{4}$ and concentrated in vacuo. The resulting residue was purified by silica gel flash chromatography (hexanes : ethyl acetate $=50: 1$ ) to give $320 \mathrm{mg}$ of compound $\mathbf{1 3}$ as a colorless oil in $91 \%$ yield. ${ }^{1} \mathrm{H}$ NMR $\left(300 \mathrm{MHz}, \mathrm{CDCl}_{3}\right) \delta$ $9.69(\mathrm{~s}, 1 \mathrm{H}), 4.91(\mathrm{~s}, 1 \mathrm{H}), 4.16-3.91(\mathrm{~m}, 3 \mathrm{H}), 3.86(\mathrm{dd}, J=4.4,2.2 \mathrm{~Hz}, 1 \mathrm{H}), 3.79$ (dd, $J=7.3$, $2.1 \mathrm{~Hz}, 1 \mathrm{H}), 3.57(\mathrm{dd}, J=16.5,10.0 \mathrm{~Hz}, 1 \mathrm{H}), 1.00-0.85(\mathrm{~m}, 29 \mathrm{H}), 0.70-0.55(\mathrm{~m}, 18 \mathrm{H}), 0.01$ $(\mathrm{s}, 9 \mathrm{H}) ;{ }^{13} \mathrm{C} \mathrm{NMR}\left(75 \mathrm{MHz}, \mathrm{CDCl}_{3}\right) \delta=198.42,98.61,83.85,75.25,72.95,69.01,67.53,18.64$, 7.21, 7.14, 5.27, 5.07, 4.98, -1.12; HRMS: calculated forC ${ }_{29} \mathrm{H}_{65} \mathrm{O}_{6} \mathrm{Si}_{4}{ }^{+}\left[\mathrm{M}+\mathrm{H}^{+}\right]$: 621.3853; found: 621.3854 .

\subsubsection{2-(Trimethylsilyl)ethyl6,7-dideoxy- $\alpha$-D-manno-hept-6-ynopyranoside (15)}

To an ice-water cooled solution of compound 13 (300 mg, $483 \mu \mathrm{mol}, 1$ equiv) and Bestmann's reagent 8 (139 mg, $724 \mu \mathrm{mol}, 1.5$ equiv) in $\mathrm{MeOH}(15 \mathrm{~mL})$ was added $\mathrm{K}_{2} \mathrm{CO}_{3}(133$ $\mathrm{mg}, 966 \mu \mathrm{mol}, 2$ equiv), and the resulting mixture was gradually warmed up to $\mathrm{rt}$ and stirred overnight. The reaction was diluted with EtOAc $(50 \mathrm{~mL})$, and washed thoroughly with water and brine. The organic layer was dried over anhydrous $\mathrm{Na}_{2} \mathrm{SO}_{4}$ and concentrated in vacuo. The resulting residue was used for next step without further purification. To a solution of the residue in THF (10 mL) was added TBAF (1.4 mL, $1.4 \mathrm{mmol}, 3$ equiv, $1 \mathrm{M}$ solution in THF), and the resulting solution was stirred at $\mathrm{rt}$ for $1 \mathrm{~h}$. The reaction was diluted with EtOAc $(50 \mathrm{~mL})$, and washed thoroughly with water and brine. The organic layer was dried over anhydrous $\mathrm{Na}_{2} \mathrm{SO}_{4}$ and concentrated in vacuo. The resulting residue was purified by silica gel flash chromatography (hexanes : ethyl acetate $=1: 1$ ) to give $95 \mathrm{mg}$ of compound $\mathbf{1 5}$ as a white solid in $72 \%$ yield over 
two steps. ${ }^{1} \mathrm{H}$ NMR $\left(500 \mathrm{MHz}, \mathrm{CDCl}_{3}\right) \delta 4.88(\mathrm{~s}, 1 \mathrm{H}), 4.32(\mathrm{dd}, J=9.4,1.7 \mathrm{~Hz}, 1 \mathrm{H}), 3.97$ (s, $1 \mathrm{H}), 3.93-3.81(\mathrm{~m}, 3 \mathrm{H}), 3.59-3.52(\mathrm{~m}, 1 \mathrm{H}), 2.62-2.55(\mathrm{~m}, 1 \mathrm{H}), 1.05-0.87(\mathrm{~m}, 2 \mathrm{H}), 0.05(\mathrm{~s}$, $9 \mathrm{H}) ;{ }^{13} \mathrm{C} \mathrm{NMR}\left(126 \mathrm{MHz}, \mathrm{CDCl}_{3}\right) \delta=99.64,80.58,74.55,71.08,70.99,70.61,65.92,63.35$, 17.98, -1.33; HRMS: calculated forC ${ }_{12} \mathrm{H}_{23} \mathrm{O}_{5} \mathrm{Si}^{+}\left[\mathrm{M}+\mathrm{H}^{+}\right]$: 275.1309; found: 275.1310.

\subsubsection{6-alkynyl-D-mannose (6dAM, 3)}

The solution of compound 15 (50 mg, $182.2 \mu \mathrm{mol}, 1$ equiv) in aq. $\mathrm{H}_{2} \mathrm{SO}_{4}(10 \mathrm{~mL}, 0.1 \% \mathrm{v} / \mathrm{v})$ was stirred at $80{ }^{\circ} \mathrm{C}$ overnight. After cooled with ice-water bath, the reaction was neutralized with $\mathrm{NaHCO}_{3}$ to $\mathrm{pH} 7$ and concentrated in vacuo. The resulting residue was purified by silica gel flash chromatography (chloroform : methanol $=5: 1$ ) to give $25 \mathrm{mg}$ of compound 3 as a white solid in 79\% yield. ${ }^{1} \mathrm{H}$ NMR $\left(500 \mathrm{MHz}, \mathrm{D}_{2} \mathrm{O}\right) \delta 5.08(\mathrm{~s}, 1 \mathrm{H}), 4.82(\mathrm{~s}, 0.4 \mathrm{H}), 4.41(\mathrm{~d}, J=9.3 \mathrm{~Hz}$, 1H), $4.00(\mathrm{dd}, J=9.5,1.5 \mathrm{~Hz}, 0.4 \mathrm{H}), 3.84(\mathrm{~d}, J=8.5 \mathrm{~Hz}, 1.4 \mathrm{H}), 3.75-3.63(\mathrm{~m}, 2 \mathrm{H}), 3.60(\mathrm{t}, J$ $=9.7 \mathrm{~Hz}, 0.4 \mathrm{H}), 3.53(\mathrm{dd}, J=9.7,2.8 \mathrm{~Hz}, 0.4 \mathrm{H}), 2.91-2.77(\mathrm{~m}, 1.4 \mathrm{H}) ;{ }^{13} \mathrm{C} \mathrm{NMR}(126 \mathrm{MHz}$, $\left.\mathrm{D}_{2} \mathrm{O}\right) \delta=94.29,93.94,80.07,79.35,75.57,75.33,72.14,70.84,70.30,70.25,69.89,69.54$, 66.62, 63.19; HRMS: calculated for $\mathrm{C}_{7} \mathrm{H}_{9} \mathrm{O}_{5}{ }^{-}\left[\mathrm{M}-\mathrm{H}^{+}\right]$: 173.0455 ; found: 173.0464 .

\subsubsection{6-alkynyl-D-mannose tetraacetate (16)}

To an ice-water cooled solution of compound 3 (17.4 mg, $100 \mu \mathrm{mol}, 1$ equiv) in pyridine (2 $\mathrm{mL})$ was added $\mathrm{Ac}_{2} \mathrm{O}(94 \mu \mathrm{L}, 1.0 \mathrm{mmol}, 10$ equiv), and the resulting solution was stirred at $\mathrm{rt}$ overnight. After completion, the reaction mixture was concentrated in vacuo, and the resulting residue was purified by silica gel flash chromatography (hexanes : ethyl acetate $=3: 1$ ) to give 30mg of compound 16 as a white solid in $88 \%$ yield. ${ }^{1} \mathrm{H}$ NMR $\left(500 \mathrm{MHz}, \mathrm{CDCl}_{3}\right) \delta 6.85(\mathrm{~s}, 1 \mathrm{H})$, $6.13(\mathrm{~s}, 0.7 \mathrm{H}), 5.60-5.34(\mathrm{~m}, 3.8 \mathrm{H}), 5.34-5.18(\mathrm{~m}, 2.5 \mathrm{H}), 4.60(\mathrm{~d}, J=9.7 \mathrm{~Hz}, 0.7 \mathrm{H}), 2.52(\mathrm{~s}$,

$0.7 \mathrm{H}), 2.46(\mathrm{~s}, 1 \mathrm{H}), 2.22-1.94(\mathrm{~m}, 27 \mathrm{H}) ;{ }^{13} \mathrm{C} \mathrm{NMR}\left(126 \mathrm{MHz}, \mathrm{CDCl}_{3}\right) \delta=169.85,169.59$, 169.34, 169.25, 168.83, 168.56, 168.27, 90.16, 86.02, 75.37, 75.04, 68.89, 68.25, 68.12, 68.07, 67.17, 66.74, 63.59, 61.04, 20.84, 20.76, 20.69, 20.61, 20.58, 20.54; HRMS: calculated for $\mathrm{C}_{15} \mathrm{H}_{18} \mathrm{NaO}_{9}{ }^{+}\left[\mathrm{M}+\mathrm{Na}^{+}\right]$: 365.0843; found: 365.0840. 
4.3. General procedure for the synthesis of compounds 2, 3, and 4 in Scheme 2D and Scheme 3

\subsubsection{General procedure for the TBDMS protection of 6-OH of free sugars}

To an ice-water cooled solution of D-glucose, L- or D-mannose (5.4 g, 30 mmol, 1 equiv) in dry pyridine $(50 \mathrm{~mL})$ was added tert-butyldimethylsilyl chloride (5.4 g, $36 \mathrm{mmol}, 1.2$ equiv) portionwise. The ice-water bath was removed after addition, and the reaction mixture was stirred at $\mathrm{rt}$ overnight. The solution was diluted with ethyl acetate $(250 \mathrm{~mL})$ and washed thoroughly with aq. $\mathrm{HCl}(0.5 \mathrm{M})$ and brine. The residue of concentrated organic layer was purified on flash silica gel chromatography (dichloromethane $:$ methanol $=15: 1$ ).

6-O-tert-butyldimethylsilyl-D-mannose (17): 50\% yield, a white solid. ${ }^{1} \mathbf{H}$ NMR (500 MHz, MeOD) $\delta 5.08(\mathrm{~s}, 1 \mathrm{H}), 3.96(\mathrm{dd}, J=11.0,2.2 \mathrm{~Hz}, 1 \mathrm{H}), 3.85(\mathrm{dd}, J=11.0,5.9 \mathrm{~Hz}, 1 \mathrm{H}), 3.81-$ $3.73(\mathrm{~m}, 3 \mathrm{H}), 3.61(\mathrm{t}, J=9.4 \mathrm{~Hz}, 1 \mathrm{H}), 0.94(\mathrm{~s}, 9 \mathrm{H}), 0.16-0.08(\mathrm{~m}, 6 \mathrm{H}) ;{ }^{13} \mathrm{C} \mathbf{N M R}(126 \mathrm{MHz}$, MeOD) $\delta=94.39,72.97,71.49,70.99,67.66,63.54,25.10,17.98,-6.51$; HRMS: calculated for $\mathrm{C}_{12} \mathrm{H}_{26} \mathrm{NaO}_{6} \mathrm{Si}^{+}\left[\mathrm{M}+\mathrm{Na}^{+}\right]: 317.1391$; found: 317.1389 .

6-O-tert-butyldimethylsilyl-D-glucose: $46 \%$ yield, a white foam. ${ }^{1} \mathbf{H}$ NMR $\left(\mathrm{MeOH}_{4}, 360 \mathrm{MHz}\right.$, ppm): $\delta 0.08(\mathrm{~s}, 6 \mathrm{H}), 0.91(\mathrm{~s}, 9 \mathrm{H}), 3.09-3.11(\mathrm{~m}, 0.45 \mathrm{H}), 3.31-3.37(\mathrm{~m}, 4 \mathrm{H}$, solvent residue peak included), 3.64-3.69 (t, $J=9.0,9,4 \mathrm{~Hz}, 0.57 \mathrm{H}), 3.74-3.85(\mathrm{~m}, 2 \mathrm{H}), 3.93-3.97(\mathrm{~d}, J=11.1 \mathrm{~Hz}$, $0.50 \mathrm{H}), 4.43-4.45(\mathrm{~d}, J=7.6 \mathrm{~Hz}, 0.46 \mathrm{H}), 5.08-5.09(\mathrm{~d}, J=3.2 \mathrm{~Hz}, 0.49 \mathrm{H}) ;{ }^{13} \mathbf{C}$ NMR $\left(\mathrm{MeOH}_{-} \mathrm{d}_{4}, 90 \mathrm{MHz}, \mathrm{ppm}\right) \delta-5.14,-5.02,19.34,26.45,64.13,64.30,71.50,71.56,73.20,73.84$, 74.91, 76.23, 78.23, 93.92, 98.12, 101.37; HRMS: calculated for $\mathrm{C}_{12} \mathrm{H}_{26} \mathrm{NaO}_{6} \mathrm{Si}^{+}\left[\mathrm{M}+\mathrm{Na}^{+}\right]$: 317.1391; found: 317.1392 .

6-O-tert-butyldimethylsilyl-L-mannose: $54 \%$ yield, a white solid in. ${ }^{1} \mathrm{H}$ NMR (500 MHz, MeOD) $\delta 5.08(\mathrm{~s}, 1 \mathrm{H}), 3.96(\mathrm{dd}, J=11.0,2.2 \mathrm{~Hz}, 1 \mathrm{H}), 3.85(\mathrm{dd}, J=11.0,5.9 \mathrm{~Hz}, 1 \mathrm{H}), 3.81-3.73(\mathrm{~m}$, 
$3 \mathrm{H}), 3.61(\mathrm{t}, J=9.4 \mathrm{~Hz}, 1 \mathrm{H}), 0.94(\mathrm{~s}, 9 \mathrm{H}), 0.16-0.08(\mathrm{~m}, 6 \mathrm{H}) ;{ }^{13} \mathrm{C} \mathrm{NMR}(126 \mathrm{MHz}, \mathrm{MeOD}) \delta$ $=94.39,72.97,71.49,70.99,67.66,63.54,25.10,17.98,-6.51$; HRMS: calculated for $\mathrm{C}_{12} \mathrm{H}_{26} \mathrm{NaO}_{6} \mathrm{Si}^{+}\left[\mathrm{M}+\mathrm{Na}^{+}\right]$: 317.1391; found: 317.1389.

\subsubsection{General procedure for the synthesis of compounds 18, 21 and 24}

To an ice-water cooled solution of 6-O-TBDMS sugars ( $0.40 \mathrm{~g}, 1.4 \mathrm{mmol}, 1$ equiv), DIPEA (1.4 mL, $8.2 \mathrm{mmol}, 6$ equiv) and TBAI (103 mg, $0.28 \mathrm{mmol}, 0.2$ equiv) in dry THF (20 mL) was added methoxymethyl chloride $(520 \mu \mathrm{L}, 6.8 \mathrm{mmol}, 5$ equiv) dropwise. The ice-water bath was removed after addition, and the reaction mixture was refluxed overnight. After completion, the reaction mixture was diluted with ethyl acetate $(100 \mathrm{~mL})$ and washed thoroughly with diluted hydrochloric acid $(0.5 \mathrm{M})$ and brine. The residue of concentrated organic layer was used for next step without further purification. To the solution of the residue in THF $(20 \mathrm{~mL})$ was added TBAF (530 mg, $2.0 \mathrm{mmol}, 1.5$ equiv), and the resulting reaction mixture was stirred at room temperature for 1 hour. After completion, the reaction was diluted with ethyl acetate $(100 \mathrm{~mL})$ and washed thoroughly with water and brine. After concentration in vacuo, the resulting residue was purified on silica gel flash chromatography (hexanes : acetone $=3: 1$ ).

1,2,3,4-tetra-O-methoxymethyl-D-mannose (18): 83\% yield, a white foam. ${ }^{\mathbf{1}} \mathbf{H}$ NMR (500 MHz, $\left.\mathrm{CDCl}_{3}\right) \delta 5.15(\mathrm{~d}, J=1.5 \mathrm{~Hz}, 1 \mathrm{H}), 4.93-4.85(\mathrm{~m}, 2 \mathrm{H}), 4.84-4.71(\mathrm{~m}, 4 \mathrm{H}), 4.69(\mathrm{~d}, J=6.3 \mathrm{~Hz}$

$1 \mathrm{H}), 4.58(\mathrm{~d}, J=6.5 \mathrm{~Hz}, 1 \mathrm{H}), 4.03(\mathrm{dd}, J=9.6,3.1 \mathrm{~Hz}, 1 \mathrm{H}), 3.99-3.91(\mathrm{~m}, 2 \mathrm{H}), 3.90-3.80(\mathrm{~m}$, 2H), $3.73-3.65(\mathrm{~m}, 1 \mathrm{H}), 3.46-3.40(\mathrm{~m}, 12 \mathrm{H}) ;{ }^{13} \mathbf{C} \mathbf{N M R}\left(126 \mathrm{MHz}, \mathrm{CDCl}_{3}\right) \delta=98.54,96.95$, 96.13, 95.51, 92.98, 76.25, 75.28, 73.29, 72.44, 62.18, 56.29, 56.22, 55.69, 55.64; HRMS: calculated for $\mathrm{C}_{14} \mathrm{H}_{28} \mathrm{NaO}_{10}{ }^{+}\left[\mathrm{M}+\mathrm{Na}^{+}\right]$: 379.1575; found: 379.1581 .

1,2,3,4-tetra-O-methoxymethyl-D-glucose (21): $88 \%$ yield, a white foam. ${ }^{\mathbf{1}} \mathbf{H} \mathbf{N M R}\left(\mathrm{CDCl}_{3}, 360\right.$ MHz, ppm): $\delta$ 2.72-2.76 (m, $1 \mathrm{H}), 3.27-3.38$ (m, $13 \mathrm{H}), 3.52-3.63(\mathrm{~m}, 2 \mathrm{H}), 3.76-3.78$ (m, $1.8 \mathrm{H})$, 4.52-4.56 (m, 1.6 H), 4.65-4.77 (m, 3.2 H), 4.83-4.87 (m, 2.8 H), 4.93-4.95 (m, $1 \mathrm{H}) ;{ }^{13} \mathbf{C}$ NMR 
$\left(\mathrm{CDCl}_{3}, 90 \mathrm{MHz}, \mathrm{ppm}\right) \delta$ 55.66, 56.11, 56.18, 56.30, 56.38, 56.46, 61.59, 71.34, 75.17, 76.36, 76.57, 76.80, 77.16, 77.36, 77.51, 77.61, 77.94, 78.24, 80.91, 93.60, 94.83, 97.10, 97.42, 98.22, 98.41, 98.93; HRMS: calculated for $\mathrm{C}_{14} \mathrm{H}_{28} \mathrm{NaO}_{10}{ }^{+}\left[\mathrm{M}+\mathrm{Na}^{+}\right]$: 379.1575 ; found: 379.1581 .

1,2,3,4-tetra-O-methoxymethyl-L-mannose (24): 76\% yield, a white foam. ${ }^{1} \mathbf{H}$ NMR (500 MHz, $\left.\mathrm{CDCl}_{3}\right) \delta 5.15(\mathrm{~d}, J=1.5 \mathrm{~Hz}, 1 \mathrm{H}), 4.93-4.85(\mathrm{~m}, 2 \mathrm{H}), 4.84-4.71(\mathrm{~m}, 4 \mathrm{H}), 4.69(\mathrm{~d}, J=6.3 \mathrm{~Hz}$, $1 \mathrm{H}), 4.58(\mathrm{~d}, J=6.5 \mathrm{~Hz}, 1 \mathrm{H}), 4.03(\mathrm{dd}, J=9.6,3.1 \mathrm{~Hz}, 1 \mathrm{H}), 3.99-3.91(\mathrm{~m}, 2 \mathrm{H}), 3.90-3.80(\mathrm{~m}$, 2H), $3.73-3.65(\mathrm{~m}, 1 \mathrm{H}), 3.46-3.40(\mathrm{~m}, 12 \mathrm{H}) ;{ }^{13} \mathbf{C} \mathbf{N M R}\left(126 \mathrm{MHz}, \mathrm{CDCl}_{3}\right) \delta=98.54,96.95$, $96.13,95.51,92.98,76.25,75.28,73.29,72.44,62.18,56.29,56.22,55.69,55.64$; HRMS: calculated for $\mathrm{C}_{14} \mathrm{H}_{28} \mathrm{NaO}_{10}{ }^{+}\left[\mathrm{M}+\mathrm{Na}^{+}\right]$: 379.1575 ; found: 379.1580 .

\subsubsection{General procedure for the synthesis of compounds 20, 22 and 25}

To an ice-water cooled solution of compound 18, 21 or 24 (356 mg, 1.0 mmol, 1 equiv) in DCM (35 mL) was added Dess-Martin periodinane (636 mg, $1.5 \mathrm{mmol}, 1.5$ equiv). The reaction mixture was stirred at $\mathrm{rt}$ for $5 \mathrm{~h}$. After completion, the milky solution was washed thoroughly with saturated aq. solution of sodium thiosulfate and brine. The organic layer was dried over sodium sulfate and concentrated. The resulting residue was used for next step without further purification. To an ice-water cooled solution of the residue and Bestmann's reagent 8 (288 $\mathrm{mg}$, $1.5 \mathrm{mmol}, 1.5$ equiv) in $\mathrm{MeOH}(20 \mathrm{~mL})$ was added $\mathrm{K}_{2} \mathrm{CO}_{3}(276 \mathrm{mg}, 2.0 \mathrm{~mol}, 2$ equiv), and the

resulting mixture was gradually warmed up to $\mathrm{rt}$ and stirred overnight. The reaction was diluted with EtOAc $(50 \mathrm{~mL})$, and washed thoroughly with water and brine. The organic layer was dried over anhydrous $\mathrm{Na}_{2} \mathrm{SO}_{4}$ and concentrated in vacuo. The resulting residue was purified by silica gel flash chromatography (hexanes : ethyl acetate $=2: 1$ ).

1,2,3,4-tetra-O-methoxymethyl-D-manno-hept-6-ynopyranose (20): $60 \%$ yield, a white foam. ${ }^{1} \mathrm{H}$ NMR $\left(500 \mathrm{MHz}, \mathrm{CDCl}_{3}\right) \delta 5.17(\mathrm{~d}, J=1.5 \mathrm{~Hz}, 1 \mathrm{H}), 4.94(\mathrm{~d}, J=6.4 \mathrm{~Hz}, 1 \mathrm{H}), 4.90(\mathrm{q}, J=6.4 \mathrm{~Hz}$, 2H), $4.84-4.74(\mathrm{~m}, 4 \mathrm{H}), 4.60(\mathrm{~d}, J=6.4 \mathrm{~Hz}, 1 \mathrm{H}), 4.39(\mathrm{dd}, J=9.4,1.7 \mathrm{~Hz}, 1 \mathrm{H}), 4.02(\mathrm{t}, J=9.4$ 
$\mathrm{Hz}, 1 \mathrm{H}), 3.96(\mathrm{dd}, J=9.4,2.9 \mathrm{~Hz}, 1 \mathrm{H}), 3.93-3.89(\mathrm{~m}, 1 \mathrm{H}), 3.50-3.41(\mathrm{~m}, 12 \mathrm{H}), 2.49(\mathrm{~d}, J=$ $2.1 \mathrm{~Hz}, 1 \mathrm{H}) ;{ }^{13} \mathrm{C} \mathrm{NMR}\left(126 \mathrm{MHz}, \mathrm{CDCl}_{3}\right) \delta=97.79,97.07,96.54,95.44,93.29,80.95,75.54$, 75.25, 75.21, 73.77, 63.38, 56.54, 56.29, 55.78, 55.72; HRMS: calculated for $\mathrm{C}_{15} \mathrm{H}_{26} \mathrm{NaO}_{9}{ }^{+}$ $\left[\mathrm{M}+\mathrm{Na}^{+}\right]: 373.1469$; found: 374.1467 .

1,2,3,4-tetra-O-methoxymethyl-D-gluco-hept-6-ynopyranose (22): $67 \%$ yield, a white foam. ${ }^{1} \mathbf{H}$ NMR (CDCl 3,360 MHz, ppm): $\delta$ 2.46-2.49 (m, 1.5 H), 3.35-3.67 (m, 23.5 H), 3.85-3.90 (m, 0.5 H), 4.02-4.06 (m, 1H), 4.38-4.41 (m, 0.5 H), 4.56-5.13 (m, $15 \mathrm{H}) ;{ }^{13} \mathbf{C ~ N M R ~}\left(\mathrm{CDCl}_{3}, 90 \mathrm{MHz}\right.$, ppm) $\delta 55.79,56.27,56.37,56.44,56.49,56.57,56.81,56.85,62.34,66.10,74.15,74.58,78.40$, 78.71, 79.69, 80.09, 80.82, 93.61, 93.97, 94.89, 97.31, 97.51, 97.84, 98.39, 98.45; HRMS: calculated for $\mathrm{C}_{15} \mathrm{H}_{26} \mathrm{NaO}_{9}{ }^{+}\left[\mathrm{M}+\mathrm{Na}^{+}\right]$: 373.1469; found: 374.1467 .

1,2,3,4-tetra-O-methoxymethyl-L-manno-hept-6-ynopyranose (25): 55\% yield, a white foam. ${ }^{1} \mathrm{H}$ NMR $\left(500 \mathrm{MHz}, \mathrm{CDCl}_{3}\right) \delta 5.17(\mathrm{~d}, J=1.5 \mathrm{~Hz}, 1 \mathrm{H}), 4.94(\mathrm{~d}, J=6.4 \mathrm{~Hz}, 1 \mathrm{H}), 4.90(\mathrm{q}, J=6.4 \mathrm{~Hz}$, 2H), $4.84-4.74(\mathrm{~m}, 4 \mathrm{H}), 4.60(\mathrm{~d}, J=6.4 \mathrm{~Hz}, 1 \mathrm{H}), 4.39(\mathrm{dd}, J=9.4,1.7 \mathrm{~Hz}, 1 \mathrm{H}), 4.02(\mathrm{t}, J=9.4$ $\mathrm{Hz}, 1 \mathrm{H}), 3.96$ (dd, $J=9.4,2.9 \mathrm{~Hz}, 1 \mathrm{H}), 3.93-3.89(\mathrm{~m}, 1 \mathrm{H}), 3.50-3.41(\mathrm{~m}, 12 \mathrm{H}), 2.49$ (d, $J=$ $2.1 \mathrm{~Hz}, 1 \mathrm{H}) ;{ }^{13} \mathrm{C}$ NMR $\left(126 \mathrm{MHz}, \mathrm{CDCl}_{3}\right) \delta=97.79,97.07,96.54,95.44,93.29,80.95,75.54$, 75.25, 75.21, 73.77, 63.38, 56.54, 56.29, 55.78, 55.72; HRMS: calculated for $\mathrm{C}_{15} \mathrm{H}_{26} \mathrm{NaO}_{9}{ }^{+}$ $\left[\mathrm{M}+\mathrm{Na}^{+}\right]: 373.1469$; found: 374.1467 .

\subsubsection{General procedure for the synthesis of compound $6 d A M(3), 6 d A G(2)$ and $6 A R$ (4)}

The solution of compound 20, 22 or 25 (100 mg, $285 \mu \mathrm{mol}, 1$ equiv) in aq. sulfuric acid (10 $\mathrm{mL}, 0.1 \% \mathrm{v} / \mathrm{v}$ ) was stirred at $80{ }^{\circ} \mathrm{C}$ overnight. After cooled with ice-water bath, the reaction was neutralized with sodium bicarbonate to $\mathrm{pH} 7$ and concentrated in vacuo. The resulting residue was purified by silica gel flash chromatography (chloroform : methanol $=5: 1$ ).

6-alkynyl-D-mannose (6dAM, 3): 68\% yield, a white solid in. ${ }^{1} \mathrm{H}$ NMR $\left(500 \mathrm{MHz}, \mathrm{D}_{2} \mathrm{O}\right) \delta 5.08(\mathrm{~s}$, 
1H), $4.82(\mathrm{~s}, 0.4 \mathrm{H}), 4.41(\mathrm{~d}, J=9.3 \mathrm{~Hz}, 1 \mathrm{H}), 4.00(\mathrm{dd}, J=9.5,1.5 \mathrm{~Hz}, 0.4 \mathrm{H}), 3.84(\mathrm{~d}, J=8.5$ Hz, $1.4 \mathrm{H}), 3.75-3.63(\mathrm{~m}, 2 \mathrm{H}), 3.60(\mathrm{t}, J=9.7 \mathrm{~Hz}, 0.4 \mathrm{H}), 3.53(\mathrm{dd}, J=9.7,2.8 \mathrm{~Hz}, 0.4 \mathrm{H})$, $2.91-2.77(\mathrm{~m}, 1.4 \mathrm{H}) ;{ }^{13} \mathrm{C}$ NMR $\left(126 \mathrm{MHz}, \mathrm{D}_{2} \mathrm{O}\right) \delta=94.29,93.94,80.07,79.35,75.57,75.33$, 72.14, 70.84, 70.30, 70.25, 69.89, 69.54, 66.62, 63.19; HRMS: calculated for $\mathrm{C}_{7} \mathrm{H}_{9} \mathrm{O}_{5}{ }^{-}\left[\mathrm{M}-\mathrm{H}^{+}\right]$: 173.0455; found: 173.0464 .

6-alkynyl-D-glucose (6dAG, 2): $80 \%$ yield, a white solid. ${ }^{1} \mathbf{H}$ NMR (MeOH-d $\left.{ }_{4}, 400 \mathrm{MHz}, \mathrm{ppm}\right)$ : $\delta 2.74-2.75(\mathrm{~d}, J=1.8 \mathrm{~Hz}, 1 \mathrm{H}), 2.82-2.83(\mathrm{~d}, J=1.8 \mathrm{~Hz}, 0.62 \mathrm{H}), 3.08-3.12(\mathrm{t}, J=8.4,8.4 \mathrm{~Hz}$, $0.7 \mathrm{H}), 3.23-3.34(\mathrm{~m}, 8 \mathrm{H}), 3.54-3.58(\mathrm{t}, J=9.2,9.2 \mathrm{~Hz}, 1 \mathrm{H}), 3.92-3.94(\mathrm{~d}, J=7.6 \mathrm{~Hz}, 0.7 \mathrm{H})$, 4.39-4.43 (m, 1.7 H), 5.02-5.03 (d, $J=3.6 \mathrm{~Hz}, 1 \mathrm{H}) ;{ }^{13} \mathbf{C}$ NMR $\left(\mathrm{MeOH}_{-} \mathrm{d}_{4}, 100 \mathrm{MHz}, \mathrm{ppm}\right) \delta$ $62.41,67.01,72.14,72.87,73.09,73.76,73.94,74.26,74.52,75.89,80.02,81.06,92.71,96.83$;

HRMS: calculated for $\mathrm{C}_{7} \mathrm{H}_{9} \mathrm{O}_{5}{ }^{-}$[M-H $\left.{ }^{+}\right]$: 173.0455; found: 173.0464 .

6-alkynyl-L-mannose $(6 A R, 4): 70 \%$ yield, a white solid. ${ }^{1} \mathrm{H} \mathrm{NMR}\left(500 \mathrm{MHz}, \mathrm{D}_{2} \mathrm{O}\right) \delta 5.08(\mathrm{~s}$, 1H), $4.82(\mathrm{~s}, 0.4 \mathrm{H}), 4.41(\mathrm{~d}, J=9.3 \mathrm{~Hz}, 1 \mathrm{H}), 4.00(\mathrm{dd}, J=9.5,1.5 \mathrm{~Hz}, 0.4 \mathrm{H}), 3.84$ (d, $J=8.5$ Hz, $1.4 \mathrm{H}), 3.75-3.63(\mathrm{~m}, 2 \mathrm{H}), 3.60(\mathrm{t}, J=9.7 \mathrm{~Hz}, 0.4 \mathrm{H}), 3.53(\mathrm{dd}, J=9.7,2.8 \mathrm{~Hz}, 0.4 \mathrm{H})$, $2.91-2.77(\mathrm{~m}, 1.4 \mathrm{H}) ;{ }^{13} \mathrm{C}$ NMR $\left(126 \mathrm{MHz}, \mathrm{D}_{2} \mathrm{O}\right) \delta=94.29,93.94,80.07,79.35,75.57,75.33$, 72.14, 70.84, 70.30, 70.25, 69.89, 69.54, 66.62, 63.19; HRMS: calculated for $\mathrm{C}_{7} \mathrm{H}_{9} \mathrm{O}_{5}{ }^{-}\left[\mathrm{M}-\mathrm{H}^{+}\right]$: 173.0455; found: 173.0464 .

\subsection{Synthesis of compound 5 in Scheme 4}

\subsubsection{6-O-acetylsucrose (29)}

To a solution of sucrose $(10.0 \mathrm{~g}, 29.2 \mathrm{mmol}, 1$ equiv) and triethylorthoacetate (7.0 mL, 38.1 mmol, 1.3 equiv) in DMF (50 mL) at $\mathrm{rt}$ was added 4-methylbenzenesulfonic acid (60 mg, 0.3 mmol, 0.01 equiv), and the resulting reaction mixture was stirred at $\mathrm{rt}$ for $3 \mathrm{~h}$.To the reaction mixture was added water $(50 \mathrm{~mL})$, and the resulting mixture was stirred at $\mathrm{rt}$ for $1 \mathrm{~h}$ followed by 
the addition of tert-butylamine $(1 \mathrm{~mL})$. After stirred at $\mathrm{rt}$ for $1.5 \mathrm{~h}$, the reaction mixture was concentrated in vacuo, and the resulting residue was purified by silica gel flash chromatography (dichloromethane : methanol $=5: 1$ ) to give $4.9 \mathrm{~g}$ of compound $\mathbf{2 9}$ as a white foam in $44 \%$ yield. ${ }^{1} \mathrm{H}$ NMR (500 MHz, DMSO) $\delta 5.27-5.08(\mathrm{~m}, 3 \mathrm{H}), 5.03(\mathrm{~d}, J=5.7 \mathrm{~Hz}, 1 \mathrm{H}), 4.90(\mathrm{~d}, J=$ $4.8 \mathrm{~Hz}, 1 \mathrm{H}), 4.82(\mathrm{t}, J=6.1 \mathrm{~Hz}, 1 \mathrm{H}), 4.58(\mathrm{~d}, J=7.8 \mathrm{~Hz}, 1 \mathrm{H}), 4.46-4.34(\mathrm{~m}, 1 \mathrm{H}), 4.23(\mathrm{~d}, J=$ $11.3 \mathrm{~Hz}, 1 \mathrm{H}), 4.14-4.05(\mathrm{~m}, 1 \mathrm{H}), 4.00(\mathrm{dd}, J=11.4,6.3 \mathrm{~Hz}, 1 \mathrm{H}), 3.95-3.80(\mathrm{~m}, 2 \mathrm{H}), 3.79-$ $3.67(\mathrm{~m}, 1 \mathrm{H}), 3.64-3.44(\mathrm{~m}, 4 \mathrm{H}), 3.44-3.26(\mathrm{~m}, 3 \mathrm{H}), 3.25-3.10(\mathrm{~m}, 3 \mathrm{H}), 3.09-2.98(\mathrm{~m}, 1 \mathrm{H})$,

$2.03(\mathrm{~s}, 3 \mathrm{H}) ;{ }^{13} \mathrm{C}$ NMR (126 MHz, DMSO) $\delta=170.90,104.31,91.84,83.20,77.31,74.93,73.13$, 71.97, 70.66, 70.40, 64.27, 63.07, 62.67, 49.07, 21.16; HRMS: calculated for $\mathrm{C}_{14} \mathrm{H}_{24} \mathrm{NaO}_{12}{ }^{+}$ $\left[\mathrm{M}+\mathrm{Na}^{+}\right]:$407.1160; found: 407.1161.

\subsubsection{1',2,3,3',4,4',6'-hepta-O-triethylsilylsucrose (30)}

To an ice-water cooled solution of compound 29 (384.3 mg, $1.0 \mathrm{mmol}$, 1 equiv) and triethylamine $(5.6 \mathrm{~mL}, 40.0 \mathrm{mmol}, 40$ equiv) in DCM $(100 \mathrm{~mL})$ was added TESOTf $(4.5 \mathrm{~mL}$, $20.0 \mathrm{mmol}, 20$ equiv) dropwise. The reaction mixture was stirred at room temperature overnight, and quenched by adding methanol $(10 \mathrm{~mL})$. The reaction mixture was concentrated in vacuo, and the resulting residue was used for next step without further purification. To a solution of the residue in DCM $(50 \mathrm{~mL})$ at $-78{ }^{\circ} \mathrm{C}$ was added DIBAL-H $(3.1 \mathrm{~mL}, 5.0 \mathrm{mmol}, 5$ equiv, $1.6 \mathrm{M}$ solution in hexanes) dropwise. The reaction was stirred at $-78{ }^{\circ} \mathrm{C}$ for 1 hour, and then quenched by adding saturated aqueous $\mathrm{NH}_{4} \mathrm{Cl}$ solution $(10 \mathrm{~mL})$. The reaction was diluted with DCM (50 $\mathrm{mL}$ ), and washed thoroughly with water and brine. The organic layer was dried over anhydrous $\mathrm{Na}_{2} \mathrm{SO}_{4}$ and concentrated in vacuo. The resulting residue was purified by silica gel flash chromatography (hexanes : EtOAc $=10: 1$ ) to give $920 \mathrm{mg}$ of compound $\mathbf{3 0}$ as a colorless oil in $88 \%$ yield. ${ }^{1} \mathrm{H}$ NMR $\left(500 \mathrm{MHz}, \mathrm{CDCl}_{3}\right) \delta 5.29(\mathrm{~d}, J=2.2 \mathrm{~Hz}, 1 \mathrm{H}), 4.42(\mathrm{~d}, J=8.0 \mathrm{~Hz}, 1 \mathrm{H}), 4.07$ - $3.91(\mathrm{~m}, 2 \mathrm{H}), 3.91-3.77(\mathrm{~m}, 2 \mathrm{H}), 3.77-3.60(\mathrm{~m}, 4 \mathrm{H}), 3.60-3.51(\mathrm{~m}, 1 \mathrm{H}), 3.51-3.33(\mathrm{~m}$, $3 \mathrm{H}), 1.87(\mathrm{~s}, 1 \mathrm{H}), 1.09-0.81(\mathrm{~m}, 63 \mathrm{H}), 0.79-0.50(\mathrm{~m}, 42 \mathrm{H}) ;{ }^{13} \mathrm{C} \mathrm{NMR}\left(126 \mathrm{MHz}, \mathrm{CDCl}_{3}\right) \delta=$ $103.42,91.07,82.29,76.50,75.49,74.22,73.56,72.73,72.08,64.15,63.55,61.57,7.22,7.09$, 
6.99, 6.91, 6.90, 6.75, 6.62, 5.69, 5.33, 5.20, 5.12, 4.52, 4.43; HRMS: calculated for $\mathrm{C}_{54} \mathrm{H}_{120} \mathrm{NaO}_{11} \mathrm{Si}_{7}^{+}\left[\mathrm{M}+\mathrm{Na}^{+}\right]:$1163.7108; found: 1163.7110 .

\subsubsection{6-alkynylsucrose heptaacetate (32)}

To a solution of compound $30(523 \mathrm{mg}, 0.5 \mathrm{mmol}, 1$ equiv) in DCM (35 mL) at room temperature was added Dess-Martin periodinane (636 mg, $1.5 \mathrm{mmol}, 3$ equiv), and the resulting reaction mixture was stirred at room temperature for $5 \mathrm{~h}$. After completion, the reaction was diluted with DCM (50 mL), and washed thoroughly with saturated aqueous sodium thiosulfate solution, water and brine. The organic layer was dried over anhydrous $\mathrm{Na}_{2} \mathrm{SO}_{4}$ and concentrated in vacuo. The resulting residue was used for next step without further purification. To an ice-water cooled solution of the residue and Bestmann's reagent (144 mg, $750 \mu \mathrm{mol}, 1.5$ equiv) in methanol $(15 \mathrm{~mL})$ was added potassium carbonate $(138 \mathrm{mg}, 1.0 \mu \mathrm{mol}, 2$ equiv), and the resulting mixture was gradually warmed up to room temperature and stirred overnight. The reaction was diluted with EtOAc $(50 \mathrm{~mL})$, and washed thoroughly with water and brine. The organic layer was dried over anhydrous $\mathrm{Na}_{2} \mathrm{SO}_{4}$ and concentrated in vacuo. The resulting residue was used for next step without further purification. To a solution of the residue in THF (10 mL) was added TBAF (5.0 mL, $5.0 \mathrm{mmol}, 10$ equiv, $1 \mathrm{M}$ solution in THF), and the resulting solution was stirred at room temperature for 1 hour. After completion, the reaction concentrated in vacuo, and the resulting residue was used for next step without further purification. To an ice-water cooled solution of the residue in pyridine $(10 \mathrm{~mL})$ was added acetic anhydride $(943 \mu \mathrm{L}, 10.0$ mmol, 20 equiv), and the resulting solution was stirred at room temperature overnight. After completion, the reaction mixture was concentrated in vacuo, and the resulting residue was purified by silica gel flash chromatography (hexanes : ethyl acetate $=2: 1$ ) to give $125 \mathrm{mg}$ of compound 32 as a white foam in $40 \%$ yield over four steps. ${ }^{1} \mathrm{H}$ NMR (500 MHz, $\left.\mathrm{CDCl}_{3}\right) \delta 5.73$ (s, 1H), $5.51-5.26(\mathrm{~m}, 4 \mathrm{H}), 5.19(\mathrm{t}, J=9.9 \mathrm{~Hz}, 1 \mathrm{H}), 4.87-4.72(\mathrm{~m}, 2 \mathrm{H}), 4.44-4.07(\mathrm{~m}, 5 \mathrm{H})$, $2.47(\mathrm{~s}, 1 \mathrm{H}), 2.25-1.94(\mathrm{~m}, 21 \mathrm{H}) ;{ }^{13} \mathrm{C} \mathrm{NMR}\left(126 \mathrm{MHz}, \mathrm{CDCl}_{3}\right) \delta=171.04,170.56,170.18$, $170.02,169.94,169.81,169.73,169.46,169.34,168.72,104.54,89.90,79.26,78.09,75.93$, 
75.11, 75.04, 71.16, 70.33, 68.97, 63.21, 63.08, 61.35, 20.73, 20.68; HRMS: calculated for $\mathrm{C}_{27} \mathrm{H}_{34} \mathrm{NaO}_{17}{ }^{+}\left[\mathrm{M}+\mathrm{Na}^{+}\right]: 653.1688$; found: 653.1688 .

\subsection{Synthesis of compounds $\mathbf{6}$ and 7 in Scheme 5}

\subsubsection{1',2,3,3',4,4',6'-hepta-O-triethylsilyl-6-trimethylsilylethynyl-sucrose (33)}

To a solution of trimethylsilylacetylene $(29.5 \mathrm{mg}, 0.3 \mathrm{mmol}, 3$ equiv) in THF ( $5 \mathrm{~mL})$ under argon atmosphere at $-78{ }^{\circ} \mathrm{C}$ was added $n$-BuLi $(187.5 \mu \mathrm{L}, 0.3 \mathrm{mmol}, 3$ equiv, $1.6 \mathrm{M}$ solution in hexanes), and the resulting reaction mixture was gradually warmed up to $0{ }^{\circ} \mathrm{C}$. To the reaction mixture was added the solution of compound $\mathbf{3 1}$ (114.0 mg, $0.1 \mathrm{mmol}, 1$ equiv) in THF (5 mL) dropwise, and the resulting reaction mixture was stirred at $0{ }^{\circ} \mathrm{C}$ for 2 hours. After quenching by the addition of saturated aqueous solution of ammonium chloride $(10 \mathrm{~mL})$, the reaction mixture was diluted with EtOAc $(30 \mathrm{~mL})$, and washed thoroughly with water and brine. The organic layer was dried over anhydrous $\mathrm{Na}_{2} \mathrm{SO}_{4}$ and concentrated in vacuo. The resulting residue was purified by silica gel flash chromatography (hexanes : EtOAc $=5: 1$ ) to give $105 \mathrm{mg}$ of compound $\mathbf{3 3}$ as a

colorless oil in $85 \%$ yield; ${ }^{1} \mathrm{H}$ NMR $\left(500 \mathrm{MHz}, \mathrm{CDCl}_{3}\right) \delta 5.31(\mathrm{~s}, 1 \mathrm{H}), 4.50(\mathrm{~d}, J=6.7 \mathrm{~Hz}, 1 \mathrm{H})$, $4.41(\mathrm{~d}, J=7.6 \mathrm{~Hz}, 1 \mathrm{H}), 4.17-4.00(\mathrm{~m}, 2 \mathrm{H}), 3.91-3.65(\mathrm{~m}, 3 \mathrm{H}), 3.67-3.33(\mathrm{~m}, 5 \mathrm{H}), 3.04(\mathrm{~s}$, $1 \mathrm{H}), 0.99(\mathrm{dd}, J=9.5,5.3 \mathrm{~Hz}, 63 \mathrm{H}), 0.82-0.50(\mathrm{~m}, 42 \mathrm{H}), 0.18(\mathrm{~s}, 9 \mathrm{H}) ;{ }^{13} \mathrm{C} \mathrm{NMR}(126 \mathrm{MHz}$, $\left.\mathrm{CDCl}_{3}\right) \delta=104.35,103.19,91.00,82.36,74.99,74.50,74.25,74.04,73.38,64.31,63.63,62.74$, $7.18,7.12,7.00,6.95,6.93,6.82,6.63,5.65,5.37,5.21,5.19,5.14,4.52,4.37,-0.23$; HRMS: calculated for $\mathrm{C}_{59} \mathrm{H}_{128} \mathrm{NaO}_{11} \mathrm{Si}_{8}{ }^{+}\left[\mathrm{M}+\mathrm{Na}^{+}\right]$: 1259.7503 ; found: 1259.7505 .

\subsubsection{6-ethynyl-sucrose (6-ES, 6)}

To the solution of compound 33 (124 mg, $0.1 \mathrm{mmol}, 1$ equiv) in THF $(10 \mathrm{~mL})$ was added TBAF (1.6 mL, $1.6 \mathrm{mmol}, 16$ equiv, $1 \mathrm{M}$ solution in THF), and the reaction was stirred at $\mathrm{rt}$ overnight. After completion, the reaction mixture was concentrated in vacuo, and the resulting residue was purified by silica gel flash chromatography (chloroform : methanol $=5: 1$ ) to give 25 
mg of compound 6 as a gum in $68 \%$ yield. ${ }^{1} \mathrm{H}$ NMR $\left(500 \mathrm{MHz}, \mathrm{D}_{2} \mathrm{O}\right) \delta 5.36(\mathrm{~d}, J=3.6 \mathrm{~Hz}, 1 \mathrm{H})$, $4.12(\mathrm{~d}, J=8.8 \mathrm{~Hz}, 1 \mathrm{H}), 3.99(\mathrm{t}, J=8.5 \mathrm{~Hz}, 1 \mathrm{H}), 3.90(\mathrm{dd}, J=10.0,2.0 \mathrm{~Hz}, 1 \mathrm{H}), 3.85-3.74(\mathrm{~m}$, 2H), $3.74-3.64(\mathrm{~m}, 2 \mathrm{H}), 3.59(\mathrm{~s}, 2 \mathrm{H}), 3.49(\mathrm{dd}, J=9.9,3.7 \mathrm{~Hz}, 1 \mathrm{H}), 3.42(\mathrm{t}, J=9.6 \mathrm{~Hz}, 1 \mathrm{H})$, $3.26(\mathrm{~s}, 2 \mathrm{H}) ;{ }^{13} \mathrm{C}$ NMR $\left(126 \mathrm{MHz}, \mathrm{D}_{2} \mathrm{O}\right) \delta=103.68,91.97,81.26,76.37,74.08,73.87,72.28$, 70.92, 70.64, 62.35, 61.53, 61.27, 48.83; HRMS: calculated for $\mathrm{C}_{14} \mathrm{H}_{22} \mathrm{NaO}_{11}{ }^{+}\left[\mathrm{M}+\mathrm{Na}^{+}\right]$: 389.1054; found: 389.1060.

\subsubsection{6-ethynylsucrose octaacetate (34)}

To an ice-water cooled solution of compound $\mathbf{6}(10 \mathrm{mg}, 27.3 \mu \mathrm{mol}, 1$ equiv) in pyridine (1 $\mathrm{mL})$ was added acetic anhydride $(52 \mu \mathrm{L}, 546 \mu \mathrm{mol}, 20$ equiv), and the resulting solution was stirred at rt overnight. After completion, the reaction mixture was concentrated in vacuo, and the resulting residue was purified by silica gel flash chromatography (hexanes : ethyl acetate $=1: 1$ ) to give $17 \mathrm{mg}$ of compound $\mathbf{3 4}$ as a white solid in $88 \%$ yield. ${ }^{1} \mathrm{H} \mathrm{NMR}\left(500 \mathrm{MHz}, \mathrm{CDCl}_{3}\right) \delta 5.75$ $(\mathrm{s}, 1 \mathrm{H}), 5.58(\mathrm{~s}, 1 \mathrm{H}), 5.53-5.41(\mathrm{~m}, 2 \mathrm{H}), 5.38(\mathrm{t}, J=5.6 \mathrm{~Hz}, 1 \mathrm{H}), 5.29(\mathrm{t}, J=9.8 \mathrm{~Hz}, 1 \mathrm{H}), 4.90$ $(\mathrm{dd}, J=10.3,3.1 \mathrm{~Hz}, 1 \mathrm{H}), 4.42-4.27(\mathrm{~m}, 3 \mathrm{H}), 4.22(\mathrm{~s}, 3 \mathrm{H}), 2.56(\mathrm{~s}, 1 \mathrm{H}), 2.24-1.96(\mathrm{~m}, 24 \mathrm{H})$; ${ }^{13} \mathrm{C} \mathrm{NMR}\left(126 \mathrm{MHz}, \mathrm{CDCl}_{3}\right) \delta=170.55,170.13,169.89,169.70,169.54,169.37,104.14,90.08$, $79.21,75.81,75.64,75.07,70.61,70.06,69.55,68.65,63.69,62.76,62.36,20.84,20.75,20.68$, 20.60; HRMS: calculated for $\mathrm{C}_{30} \mathrm{H}_{38} \mathrm{NaO}_{19}{ }^{+}\left[\mathrm{M}+\mathrm{Na}^{+}\right]$: 725.1900 ; found: 725.1900.

\subsubsection{6-ethynylglucose pentaacetate (37)}

To a solution of trimethylsilylacetylene $(147 \mathrm{mg}, 1.5 \mathrm{mmol}, 3$ equiv) in THF (20 mL) under argon atmosphere at $-78{ }^{\circ} \mathrm{C}$ was added $n$-BuLi $(938 \mu \mathrm{L}, 1.5 \mathrm{mmol}, 3$ equiv, $1.6 \mathrm{M}$ solution in hexanes), and the resulting reaction mixture was gradually warmed up to $0{ }^{\circ} \mathrm{C}$. To the reaction mixture was added the solution of compound 35 (177 mg, $0.5 \mathrm{mmol}, 1$ equiv) in THF (10 mL)

dropwise, and the resulting reaction mixture was stirred at $0{ }^{\circ} \mathrm{C}$ for 2 hours. After quenching by the addition of saturated aqueous solution of ammonium chloride $(30 \mathrm{~mL})$, the reaction mixture was diluted with EtOAc $(100 \mathrm{~mL})$, and washed thoroughly with water and brine. The organic 
layer was dried over anhydrous $\mathrm{Na}_{2} \mathrm{SO}_{4}$ and concentrated in vacuo. The resulting residue was used for next step without further purification. To the solution of the residue in THF $(10 \mathrm{~mL})$ was added TBAF (1.0 mL, $1.0 \mathrm{mmol}, 2$ equiv, $1 \mathrm{M}$ solution in THF), and the reaction was stirred at room temperature for 1 hour. After completion, the reaction mixture was diluted with EtOAc (50 $\mathrm{mL}$ ) and washed thoroughly with water and brine. The organic layer was concentrated in vacuo, and the resulting residue was used for next step without further purification. The solution of the residue in diluted sulfuric acid $(10 \mathrm{~mL}, 0.1 \% \mathrm{v} / \mathrm{v})$ was stirred at $80{ }^{\circ} \mathrm{C}$ overnight. After cooled with ice-water bath, the reaction was neutralized with sodium bicarbonate to $\mathrm{pH} 7$ and concentrated in vacuo. The resulting residue was used for next step without further purification. To an ice-water cooled solution of the residue in pyridine $(10 \mathrm{~mL})$ was added acetic anhydride (471 $\mu \mathrm{L}, 5.0 \mathrm{mmol}, 10$ equiv), and the resulting solution was stirred at rt overnight. After completion, the reaction mixture was concentrated in vacuo, and the resulting residue was purified by silica gel flash chromatography (hexanes : ethyl acetate $=2: 1$ ) to give $110 \mathrm{mg}$ of compound 37 as a white solid in $53 \%$ yield. ${ }^{1} \mathrm{H}$ NMR $\left(500 \mathrm{MHz}, \mathrm{CDCl}_{3}\right) \delta 6.47-6.28(\mathrm{~m}, 1 \mathrm{H})$, $5.83-5.66(\mathrm{~m}, 1 \mathrm{H}), 5.61-5.42(\mathrm{~m}, 3 \mathrm{H}), 5.37-5.22(\mathrm{~m}, 2 \mathrm{H}), 5.22-5.04(\mathrm{~m}, 3 \mathrm{H}), 4.29-4.10$ $(\mathrm{m}, 1 \mathrm{H}), 3.97-3.81(\mathrm{~m}, 1 \mathrm{H}), 2.57(\mathrm{~s}, 1 \mathrm{H}), 2.52(\mathrm{~d}, J=1.9 \mathrm{~Hz}, 1 \mathrm{H}), 2.25-1.88(\mathrm{~m}, 32 \mathrm{H}) ;{ }^{13} \mathrm{C}$ NMR $\left(126 \mathrm{MHz} \mathrm{CDCl}_{3}\right) \delta=170.25,170.17,169.79,169.66,169.60,169.48,169.39,169.23$, 168.81, 168.58, 91.88, 91.41, 89.03, 88.97, 76.59, 76.17, 76.14, 76.02, 75.88, 75.50, 75.22, 74.64, $74.38,72.77,72.65,71.88,71.81,70.20,69.91,69.82,69.79,69.08,68.94,68.31,67.58,67.34$ 62.26, 60.56, 60.33, 20.83, 20.78, 20.64, 20.56, 20.53, 20.44; HRMS: calculated for $\mathrm{C}_{18} \mathrm{H}_{22} \mathrm{NaO}_{11}{ }^{+}\left[\mathrm{M}+\mathrm{Na}^{+}\right]$: 437.1054; found: 437.1055 .

\section{Acknowledgments}

This work was supported as part of The Center for Lignocellulose Structure and Formation, an Energy Frontier Research Center funded by the U.S. Department of Energy, Office of Science, Basic Energy Sciences under Award \# DE-SC0001090. 


\section{Appendix: Supplementary material}

Supplementary data including NMR spectra of all new compounds can be found online.

\section{References}

(1) Fry, S. C. New Phytol.2004,161, 641-675.

(2) Cosgrove, D. J. Nat. Rev. Mol. Cell Biol.2005, 6, 850-861.

(3) Breidenbach, M. A.; Gallagher, J. E. G.; King, D. S.; Smart, B. P.; Wu, P.; Bertozzi, C. R. Proc. Natl. Acad. Sci. U. S. A.2010, 107, 3988-3993.

(4) Anderson, C. T.; Carroll, A.; Akhmetova, L.; Somerville, C. Plant Physiol. 2010, 152, 787-796.

(5) Hsu, T.-L.; Hanson, S. R.; Kishikawa, K.; Wang, S.-K.; Sawa, M.; Wong, C.-H. Proc. Natl. Acad. Sci. U. S. A.2007, 104, 2614-2619.

(6) Lukose, V.; Whitworth, G.; Guan, Z.; Imperiali, B. J. Am. Chem. Soc.2015, 137, $12446-12449$.

(7) Somerville, C.; Bauer, S.; Brininstool, G.; Facette, M.; Hamann, T.; Milne, J.; Osborne, E.; Paredez, A.; Persson, S.; Raab, T.; Vorwerk, S.; Youngs, H. Science. 2004, 306, 2206-2211.

(8) Anderson, C. T.; Wallace, I. S.; Somerville, C. R. Proc. Natl. Acad. Sci. U. S. A. 2012, 109, $1329-1334$.

(9) Kolb, H. C.; Finn, M. G.; Sharpless, K. B. Angew. Chem. Int. Ed. 2001, 40, 2004-2021.

(10) Laughlin, S. T.; Bertozzi, C. R. Proc. Natl. Acad. Sci. U. S. A.2009, 106, 12-17.

(11) Nicol, F.; Höfte, H. Curr. Opin. Plant Biol.1998, 1, 12-17.

(12) Baskin, T. I. Annu. Rev. Cell Dev. Biol.2005, 21, 203-222.

(13) Keegstra, K. Plant Physiol.2010, 154, 483-486.

(14) Lerouxel, O.; Cavalier, D. M.; Liepman, A. H.; Keegstra, K. Curr. Opin. Plant Biol. 2006,9, 621-630.

(15) Pauly, M.; Gille, S.; Liu, L.; Mansoori, N.; de Souza, A.; Schultink, A.; Xiong, G. Planta. 
2013,238, 627-642.

(16) Caffall, K. H.; Mohnen, D. Carbohydr. Res.2009, 344, 1879-1900.

(17) Cassab, G. I. Annu. Rev. Plant Physiol. Plant Mol. Biol.1998, 49, 281-309.

(18) Dumont, M.; Lehner, A.; Vauzeilles, B.; Malassis, J.; Marchant, A.; Smyth, K.; Linclau, B.; Baron, A.; Mas Pons, J.; Anderson, C. T.; Schapman, D.; Galas, L.; Mollet, J. C.; Lerouge, P. Plant J. 2016, 85, 437-447.

(19) McClosky, D. D.; Wang, B.; Chen, G.; Anderson, C. T. Phytochemistry 2016, 123, 16-24.

(20) Willats, W. G. T.; Mccartney, L.; Mackie, W.; Knox, J. P. Plant Mol. Biol. 2001, 47, 9-27.

(21) Scheller, H. V.; Jensen, J. K.; Sørensen, S. O.; Harholt, J.; Geshi, N. Physiol. Plant. 2007, $129,283-295$.

(22) Mohnen, D. Curr. Opin. Plant Biol. 2008, 11, 266-277.

(23) Hartmann, M.; Betz, P.; Sun, Y.; Gorb, S. N.; Lindhorst, T. K.; Krueger, A. Chem. - A Eur. J.2012, 18, 6485-6492.

(24) Lemoine, R. Biochim. Biophys. Acta, Biomembr. 2000, 1463, 246-262. 